\title{
三脚架型二胺基-膦配体支撑的亚铁配合物与有机重氮化合物的反应
}

\author{
刘健肖洁 Sudipta Mondal 冷雪冰双亮* \\ (中国科学院上海有机化学研究所 金属有机化学国家重点实验室 上海 200032)
}

\begin{abstract}
摘要 通过 $\mathrm{Bu}^{t} \mathrm{PCl}_{2}$ 与两倍量原位形成的邻位胺基取代苯基锂的反应合成了二胺基-膦配体 $\mathrm{H}_{2}\left({ }^{\mathrm{Mes}} \mathrm{N}_{2} \mathrm{P}^{\mathrm{Bu}-t}\right)$ 和 $\mathrm{H}_{2}\left({ }^{\mathrm{dcp}} \mathrm{N}_{2} \mathrm{P}^{\mathrm{Bu}-t}\right)$. 利用 $\mathrm{H}_{2}\left({ }^{\mathrm{Mes}} \mathrm{N}_{2} \mathrm{P}^{\mathrm{Bu}-t}\right)$ 和 $\mathrm{H}_{2}\left({ }^{\mathrm{dcp}} \mathrm{N}_{2} \mathrm{P}^{\mathrm{Bu}-t}\right)$ 与 $\left[\mathrm{Fe}\left(\mathrm{N}\left(\mathrm{SiMe}_{3}\right)_{2}\right)_{2}\right]_{2}$ 的胺消除反应合成得到二胺基-膦配位的高自旋亚 铁配合物 $\left[\left(\kappa^{3}-N, N, P_{-}{ }^{\mathrm{Mes}} \mathrm{N}_{2} \mathrm{P}^{\mathrm{Bu}-t}\right) \mathrm{Fe}\left(\mathrm{OEt}_{2}\right)\right](\mathbf{1})$ 和 $\left[\left(\kappa^{3}-N, N, P-{ }^{\mathrm{dcp}} \mathrm{N}_{2} \mathrm{P}^{\mathrm{Bu}-t}\right) \mathrm{Fe}\left(\mathrm{OEt}_{2}\right)\right](2)$. 配合物 1 与重氮化合物 $\left(p-\mathrm{tolyl}_{2}\right)_{2} \mathrm{CN}_{2}$ 和 $\mathrm{PhC}\left(\mathrm{N}_{2}\right) \mathrm{CO}_{2} \mathrm{Et}$ 反应分别生成重氮配位的铁配合物 $\left[\left(\kappa^{3}-N, N, P-{ }_{-}^{\mathrm{Mes}} \mathrm{N}_{2} \mathrm{P}^{\mathrm{Bu}-t}\right) \mathrm{Fe}\left(\eta^{2}-N, N-(p-\text { tolyl })_{2} \mathrm{CN}_{2}\right)\right](3)$ 和 $\left[\left(\kappa^{3}-N, N\right.\right.$, $\left.\left.P_{-}{ }^{\mathrm{Mes}} \mathrm{N}_{2} \mathrm{P}^{\mathrm{Bu}-t}\right) \mathrm{Fe}\left(\kappa^{2}-N, O-\mathrm{PhC}\left(\mathrm{N}_{2}\right) \mathrm{CO}_{2} \mathrm{Et}\right)\right](4)$. 配合物 2 可以催化重氮化合物 $(p \text {-tolyl })_{2} \mathrm{CN}_{2}$ 转化为酮连氮化合物 $(p \text {-tolyl })_{2}$ $\mathrm{C}=\mathrm{NN}=\mathrm{C}(\text { tolyl }-p)_{2}$. 配合物 2 与重氮化合物 $\mathrm{DmpC}\left(\mathrm{N}_{2}\right) \mathrm{H}$ 反应生成二胺基一膦叶立德配位的高自旋亚铁配合物 $\left[\left(\kappa^{3}-N, N, C-{ }^{\mathrm{dcp}} \mathrm{N}_{2} \mathrm{P}^{\mathrm{Bu}-t} \mathrm{C}^{\mathrm{H}, \mathrm{Dmp}}\right) \mathrm{Fe}\right](\mathbf{5})$. 二胺基-膦配体 $\mathrm{H}_{2}\left({ }^{\mathrm{Mes}} \mathrm{N}_{2} \mathrm{P}^{\mathrm{Bu}-t}\right)$ 和 $\mathrm{H}_{2}\left({ }^{\mathrm{dcp}} \mathrm{N}_{2} \mathrm{P}^{\mathrm{Bu}-t}\right)$ 以及配合物 $\mathbf{1} \sim \mathbf{5}$ 通过了各种谱学数据 的表征. 其中配合物 $2 \sim 5$ 的结构还通过单晶 $X$ 射线衍射得到确认. 理论计算显示配合物 3 可看作为低自旋型四价铁末 端亚胺基配合物. 配合物 $\mathbf{4}$ 的电子结构可描述为中间自旋的三价铁中心与重氮自由基阴离子反铁磁性耦合形成基态自 旋为 $S=1$ 的配合物.
\end{abstract}

关键词 铁; 重氮化合物; 二胺基-膦配体

\section{Reactions of Iron(II) Complexes Supported by Tripodal Amido- Phosphine-Amido Ligands with Diazo Compounds}

\author{
Liu, Jian Xiao, Jie Mondal, Sudipta Leng, Xuebing Deng, Liang*
}

(State Key Laboratory of Organometallic Chemistry, Shanghai Institute of Organic Chemistry,

Chinese Academy of Sciences, Shanghai 200032)

\begin{abstract}
Treatment of $\mathrm{Bu}^{t} \mathrm{PCl}_{2}$ with 2 equiv. of $\left(2,4,6-\mathrm{Me}_{3} \mathrm{C}_{6} \mathrm{H}_{2}\right)\left(2-\mathrm{LiC}_{6} \mathrm{H}_{4}\right) \mathrm{NLi}$ and $\left(2,6-\mathrm{Cl}_{2} \mathrm{C}_{6} \mathrm{H}_{3}\right)\left(2-\mathrm{LiC}_{6} \mathrm{H}_{4}\right) \mathrm{NLi}$, which were generated in situ by the interaction of $\left(2,4,6-\mathrm{Me}_{3} \mathrm{C}_{6} \mathrm{H}_{2}\right)\left(2-\mathrm{BrC}_{6} \mathrm{H}_{4}\right) \mathrm{NH}$ and $\left(2,6-\mathrm{Cl}_{2} \mathrm{C}_{6} \mathrm{H}_{3}\right)\left(2-\mathrm{BrC}_{6} \mathrm{H}_{4}\right) \mathrm{NH}$ with 2 equiv. of $\mathrm{Bu}^{n} \mathrm{Li}$, followed by quenching with water, afforded new tridentate diamine-phosphine compounds $\left(o-\left(N-\left(2,4,6-\mathrm{Me}_{3} \mathrm{C}_{6} \mathrm{H}_{2}\right)-\right.\right.$ $\left.\mathrm{NH}) \mathrm{C}_{6} \mathrm{H}_{4}\right)_{2} \mathrm{PBu}^{t}$ and $\left(o-\left(N-\left(2,6-\mathrm{Cl}_{2} \mathrm{C}_{6} \mathrm{H}_{3}\right) \mathrm{NH}\right) \mathrm{C}_{6} \mathrm{H}_{4}\right)_{2} \mathrm{PBu}^{t}$ (denoted as $\mathrm{H}_{2}\left({ }^{\text {Mes }} \mathrm{N}_{2} \mathrm{P}^{\mathrm{Bu}-t}\right)$ and $\mathrm{H}_{2}\left({ }^{\mathrm{dcp}} \mathrm{N}_{2} \mathrm{P}^{\mathrm{Bu}-t}\right)$ ), respectively. $\mathrm{H}_{2}\left({ }^{\mathrm{Mes}} \mathrm{N}_{2} \mathrm{P}^{\mathrm{Bu}-t}\right)$ and $\mathrm{H}_{2}\left({ }^{\mathrm{dcp}} \mathrm{N}_{2} \mathrm{P}^{\mathrm{Bu}-t}\right)$ underwent amine-elimination reaction with [ $\left.\mathrm{Fe}\left(\mathrm{N}\left(\mathrm{SiMe}_{3}\right)_{2}\right)_{2}\right]_{2}(0.5$ equiv.) to afford iron(II) complexes $\left[\left(\kappa^{3}-N, N, P-{ }_{-}^{\mathrm{Mes}} \mathrm{N}_{2} \mathrm{P}^{\mathrm{Bu}-t}\right) \mathrm{Fe}\left(\mathrm{OEt}_{2}\right)\right](\mathbf{1})$ and $\left[\left(\kappa^{3}-N, N, P-{ }_{-}^{\mathrm{dcp}} \mathrm{N}_{2} \mathrm{P}^{\mathrm{Bu}-t}\right) \mathrm{Fe}\left(\mathrm{OEt}_{2}\right)\right]$ (2) bearing tridentate diamido-phosphine ligands. Treatment of 1 with organic diazo compounds ( $p$-tolyl $)_{2} \mathrm{CN}_{2}$ and $\mathrm{PhC}\left(\mathrm{N}_{2}\right) \mathrm{CO}_{2}$ Et rendered the formation of diazo coordinated iron complexes $\left[\left(\kappa^{3}-N, N, P_{-}{ }^{\mathrm{Mes}} \mathrm{N}_{2} \mathrm{P}^{\mathrm{Bu}-t}\right) \mathrm{Fe}\left(\eta^{2}-N, N-(p \text {-tolyl })_{2} \mathrm{CN}_{2}\right)\right](3)$ and $\left[\left(\kappa^{3}-N, N, P-{ }^{\mathrm{Mes}} \mathrm{N}_{2} \mathrm{P}^{\mathrm{Bu}-t}\right) \mathrm{Fe}\left(\kappa^{2}-N, O-\mathrm{PhC}\left(\mathrm{N}_{2}\right)-\right.\right.$ $\left.\mathrm{CO}_{2} \mathrm{Et}\right)$ ] (4), respectively. Complex 2 can catalyze the conversion of $(p \text {-tolyl })_{2} \mathrm{CN}_{2}$ to $(p \text {-tolyl })_{2} \mathrm{C}=\mathrm{NN}=\mathrm{C}(\text { tolyl }-p)_{2}$. Treatment of 2 with organic diazo compound $\operatorname{DmpC}\left(\mathrm{N}_{2}\right) \mathrm{H}$ rendered the formation of a high-spin iron(II) complex featuring the tridentate bisamido-phosphine ylide ligand $\left[\left(\kappa^{3}-N, N, C-{ }^{\text {dcp }} \mathrm{N}_{2} \mathrm{P}^{\mathrm{Bu}-t} \mathrm{C}^{\mathrm{H}, \mathrm{Dmp}}\right) \mathrm{Fe}\right](\mathbf{5})$. These complexes have been characterized by elemental analysis, ${ }^{1} \mathrm{H}$ NMR, solution magnetic susceptibility measurements, zero-field ${ }^{57} \mathrm{Fe}$ Mössbauer spectroscopy and single-crystal X-ray diffraction studies. The spectroscopic data in combination with theoretical study suggest that complex 3 can be viewed as a low-spin iron(IV) imido complex featuring an dianionic ligand $\left[\eta^{2}-N, N-(p \text {-tolyl })_{2} \mathrm{CN}_{2}\right]^{2-}$, whereas 4 has an intermediate-spin iron(III) center that is antiferromagnetically coupled to a diazoalkane radical anion $\left[\kappa^{2}-N, O-\mathrm{PhC}\left(\mathrm{N}_{2}\right)-\right.$ $\left.\left.\mathrm{CO}_{2} \mathrm{Et}\right)\right]^{\cdot 1-}$.
\end{abstract}

Keywords iron; diazo compounds; diamido-phosphine ligand

\section{* Corresponding author. E-mail: deng@sioc.ac.cn}

Received May 29, 2020; revised June 27, 2020; published online June 30, 2020.

Dedicated to Professor Henry N. C. Wong on the occasion of his 70th birthday.

Project supported by the National Key Research and Development Program of the Ministry of Science and Technology (No. 2016YFA0202900), the Natural Science Foundation of China (Nos. 21725104, 21690062, 21821002), CAS Strategic Pilot Science And Technology Special (No. XDB20000000), and the Program of Shanghai Academic Research Leader (No. 19XD1424800).

科技部国家重点研发计划(No. 2016YFA0202900)、国家自然科学基金(Nos. 21725104, 21690062, 21821002)、中国科学院先导专项(No. XDB20000000) 和上海市优秀学术带头人计划(No. 19XD1424800)资助项目. 


\section{Introduction}

In the reactions of metal species with diazoalkanes, diazoalkane complexes ${ }^{[1-5]}$ are recognized as intermediates en route to the products, alkylidene complexes, that could facilitate useful transformations such as alkene cyclopropanation, $\mathrm{C}-\mathrm{H}$ alkylation, alkene metathesis, and so on. ${ }^{[6-10]}$ Consequently, there are great interests on the sythesis, structural feature, and reactivity of transition-metal diazoalkane complexes. The known transition-metal diazoalkane complexes are dominated by the complexes of cobalt, nickel, and ruthenium, ${ }^{[11-16]}$ whereas the diazoalkane complexes of iron are scarce, which form a sharp contrast to the soaring research interest on iron-catalyzed carbenetransfter reactions. ${ }^{[17]}$

The limited examples of iron diazoalkane complexes include the bis(imino)pyridine complex [(PDI)Fe $\left(\eta^{1}-\mathrm{N}_{2} \mathrm{CH}-\right.$ $\mathrm{SiMe}_{3}$ )] (A in Chart 1), ${ }^{[18]}$ the tris(pyrrolido)ethane iron complex $\left[(\right.$ tpe $\left.) \mathrm{Fe}\left(\eta^{1}-\mathrm{N}_{2} \mathrm{CPh}_{2}\right)\right]\left[\mathrm{Li}(\mathrm{THF})_{4}\right] \quad($ tpe $=\operatorname{tris}(5-\mathrm{me}-$ sitylpyrrolyl)ethane, B), ${ }^{[19]}$ the $\beta$-diketiminate iron complex $\left[\mathrm{L}^{\mathrm{Bu}-t} \mathrm{Fe}\left(\eta^{1}-\mathrm{N}_{2} \mathrm{CPh}_{2}\right)\right] \quad\left(\mathrm{L}^{\mathrm{Bu}-t}=\left[\left(\mathrm{DippNCBu}^{t}\right)_{2} \mathrm{CH}\right]^{-}, \mathbf{C}\right)^{[20]}$, the cyclopentadienyliron complexes $\left[\left(\eta^{5}-\mathrm{C}_{5} \mathrm{H}_{5}\right) \mathrm{Fe}\left(\eta^{1}-\mathrm{N}_{2} \mathrm{C}\right.\right.$ $\left.\left.\mathrm{Ar}^{1} \mathrm{Ar}^{2}\right)(\mathrm{P}-\mathrm{P})\right] \mathrm{BPh}_{4}$ (P-P=1,2-bis(diphenylphosphine)ethane, 1,3-bis(diphenylphosphine)propane; $\mathrm{Ar}^{1}=\mathrm{Ar}^{2}=\mathrm{Ph}$; $\mathrm{Ar}^{1}=\mathrm{Ph}, \mathrm{Ar}^{2}=p$-tolyl; $\left.\mathrm{Ar}^{1} \mathrm{Ar}^{2}=\mathrm{C}_{12} \mathrm{H}_{8}, \mathbf{D}\right),{ }^{[1]}$ as well as the side-on type diazo complexes $\left[(\mathrm{PDI}) \mathrm{Fe}\left(\eta^{2}-N, N-\mathrm{N}_{2} \mathrm{C}\right.\right.$ $\left.\left.\mathrm{Ph}_{2}\right)\right](\mathbf{E})^{[22]}$ and $\left[\mathrm{L}^{\mathrm{Bu}-t} \mathrm{Fe}\left(\eta^{2}-N, N-\mathrm{N}_{2} \mathrm{CPh}_{2}\right) \mathrm{K}\left(\mathrm{OEt}_{2}\right)\right]_{2}(\mathbf{F})^{[20]}$. Interestingly, spectroscopic and theoretical studies revealed that the diazo ligands in these complexes could be present in different electronic structures. For example, the diazoalkane ligands in $\mathbf{B}$ and $\mathbf{C}$ have been assigned as radical anions. The side-on diazoalkane ligand in $\mathbf{E}$ is thought to receive little backdonation from its iron center and can be viewed as merely a $\sigma$-donor. The side-on diazoalkane ligand in $\mathbf{F}$ on the other hand is a radical anion. In addition to the aforementioned studies, herein, we wish to report the reactions of high-spin iron(II) complexes featuring tripodal amidophosphine-amido ligands, from which two new iron diazoalkane complexes $\left[\left(\kappa^{3}-N, N, P-{ }^{\mathrm{Mes}} \mathrm{N}_{2} \mathrm{P}^{\mathrm{Bu}-t}\right) \mathrm{Fe}\left(\eta^{2}-N, N-(p\right.\right.$-tol$\left.\left.\mathrm{yl})_{2} \mathrm{CN}_{2}\right)\right]$ and $\left[\left(\kappa^{3}-N, N, P-{ }^{\mathrm{Mes}} \mathrm{N}_{2} \mathrm{P}^{\mathrm{Bu}-t}\right) \mathrm{Fe}\left(\kappa^{2}-N, O-\mathrm{PhC}\left(\mathrm{N}_{2}\right)-\right.\right.$ $\left.\left.\mathrm{CO}_{2} \mathrm{Et}\right)\right]$ have been isolated and structurally characterized.

\section{Results and discussion}

2.1 Syntheses and characterization of (amido-phosphine-amido)iron(II) complexes $\mathbf{1}$ and $\mathbf{2}$

Previously, we found that the reaction of an (amidophosphine-amido)iron(II) complex $\left[\left(\kappa^{3}-N, N, P_{-}{ }^{\mathrm{dfp}} \mathrm{N}_{2} \mathrm{P}^{\mathrm{Ph}}\right) \mathrm{Fe}-\right.$ $\left.(\mathrm{THF})_{2}\right]$ with ( $p$-tolyl $)_{2} \mathrm{CN}_{2}$ furnished a diamido-phosphine ylide iron(II) complex $\left[\left(\kappa^{3}-N, N, C-{ }^{\mathrm{dfp}} \mathrm{N}_{2} \mathrm{P}^{\mathrm{Ph}} \mathrm{C}(\text { tolyl }-p)_{2}\right)-\right.$ $\mathrm{Fe}(\mathrm{THF})]$ (Scheme 1). ${ }^{[23]}$ The ylide complex was proposed to be formed from the migratory insertion reaction of an iron(II) alkylidene intermediate. Aiming to attenuate the ease of the migratory insertion reaction of the proposed iron(II) alkylidene intermediates, new amido-phosphineamido ligands having tert-butyl on phosphorus atom were then developed.

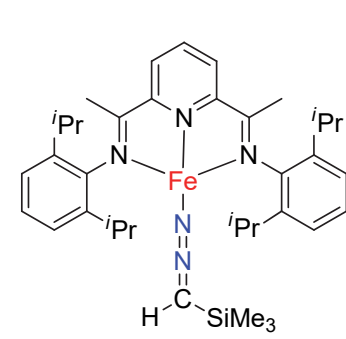

A

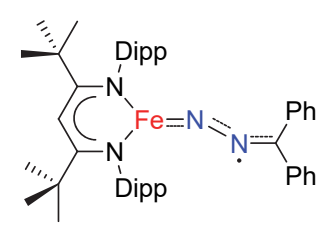

C
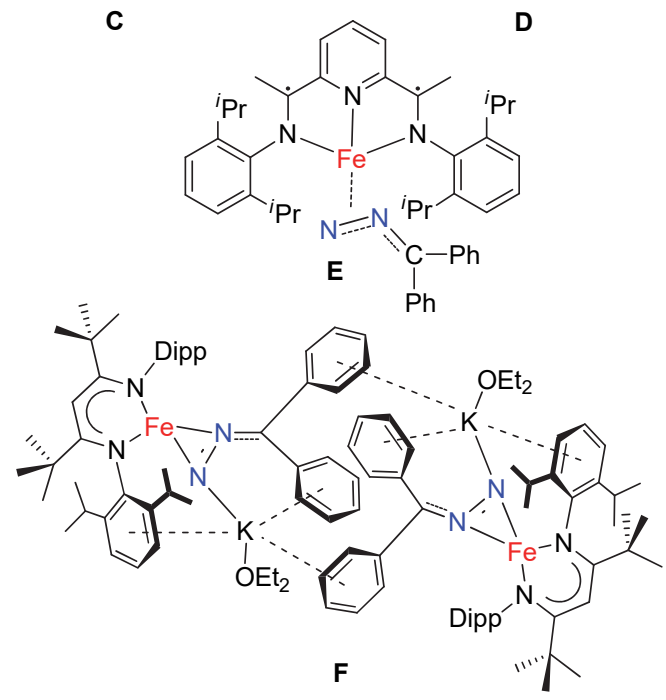

Chart 1 Examples of isolable iron diazoalkane complexes

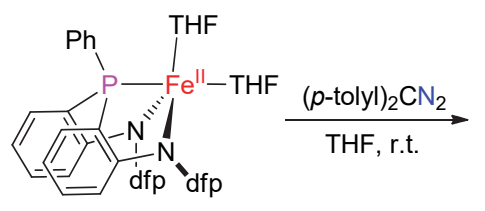

$\mathrm{dfp}=$ 2,6-difluorophenyl

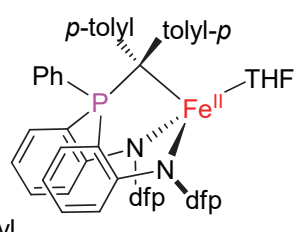

Scheme 1 Reaction of $\left[\left(\kappa^{3}-N, N, P_{-}{ }^{\mathrm{dfp}} \mathrm{N}_{2} \mathrm{P}^{\mathrm{Ph}}\right) \mathrm{Fe}(\mathrm{THF})_{2}\right]$ with $(p$ tolyl $)_{2} \mathrm{CN}_{2}$

The synthetic procedures of the new ligands $(o-(N-(2,4,6-$ $\left.\left.\left.\mathrm{Me}_{3} \mathrm{C}_{6} \mathrm{H}_{2}\right) \mathrm{NH}\right) \mathrm{C}_{6} \mathrm{H}_{4}\right)_{2} \mathrm{PBu}^{t}$ and $\left(o-\left(N-\left(2,6-\mathrm{Cl}_{2} \mathrm{C}_{6} \mathrm{H}_{3}\right) \mathrm{NH}\right)-\right.$ $\left.\mathrm{C}_{6} \mathrm{H}_{4}\right)_{2} \mathrm{PBu}^{t}$ (denoted as $\mathrm{H}_{2}\left({ }^{\mathrm{Mes}} \mathrm{N}_{2} \mathrm{P}^{\mathrm{Bu}-t}\right.$ ) and $\mathrm{H}_{2}\left({ }^{\mathrm{dcp}} \mathrm{N}_{2}-\mathrm{P}^{\mathrm{Bu}-t}\right)$ ) follow that used for $\mathrm{H}_{2}\left({ }^{\mathrm{dfp}} \mathrm{N}_{2} \mathrm{P}^{\mathrm{Ph}}\right)$. ${ }^{[23]}$ Treatment of $\mathrm{Bu}^{t} \mathrm{PCl}_{2}$ with 2 equiv. of $\left(2,4,6-\mathrm{Me}_{3} \mathrm{C}_{6} \mathrm{H}_{2}\right)\left(2-\mathrm{LiC}_{6} \mathrm{H}_{4}\right) \mathrm{NLi}$ and $(2,6-$ $\left.\mathrm{Cl}_{2} \mathrm{C}_{6} \mathrm{H}_{3}\right)\left(2-\mathrm{LiC}_{6} \mathrm{H}_{4}\right) \mathrm{NLi}$, which were generated in situ by the interaction of $\left(2,4,6-\mathrm{Me}_{3} \mathrm{C}_{6} \mathrm{H}_{2}\right)\left(2-\mathrm{BrC}_{6} \mathrm{H}_{4}\right) \mathrm{NH}$ and $(2,6-$ $\left.\mathrm{Cl}_{2} \mathrm{C}_{6} \mathrm{H}_{3}\right)\left(2-\mathrm{BrC}_{6} \mathrm{H}_{4}\right) \mathrm{NH}$ with 2 equiv. of $\mathrm{Bu}^{n} \mathrm{Li}$, followed by quenching with water, afforded the amine-phosphine-amine compounds $\mathrm{H}_{2}\left({ }^{\mathrm{Mes}} \mathrm{N}_{2} \mathrm{P}^{\mathrm{Bu}-t}\right)$ and $\mathrm{H}_{2}\left({ }^{\mathrm{dcp}} \mathrm{N}_{2} \mathrm{P}^{\mathrm{Bu}-t}\right)$ in $50 \%$ and $53 \%$ isolated yields, respectively (Scheme 2). $\mathrm{H}_{2}\left({ }^{\mathrm{Mes}} \mathrm{N}_{2}\right.$ $\left.\mathrm{P}^{\mathrm{Bu}-t}\right)$ and $\mathrm{H}_{2}\left({ }^{\mathrm{dcp}} \mathrm{N}_{2} \mathrm{P}^{\mathrm{Bu}-t}\right)$ have been characterized by NMR, FT-IR and HRMS. 


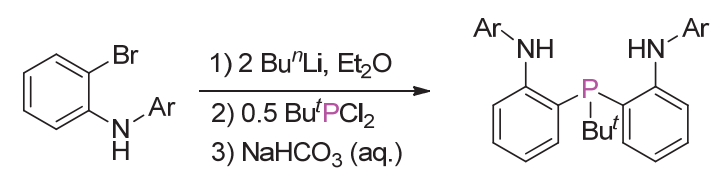

$\mathrm{Ar}=$ 2,4,6-trimethylphenyl, Mes; 2,6-dichlorophenyl, dcp

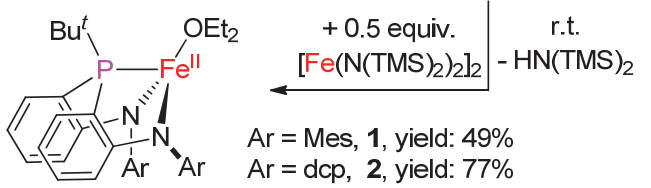

Scheme 2 Synthetic route to the (amido-phosphineamido)iron(II) complexes $\mathbf{1}$ and $\mathbf{2}$

The new amine-phosphine-amine ligands $\mathrm{H}_{2}\left({ }^{\mathrm{Mes}} \mathrm{N}_{2} \mathrm{P}^{\mathrm{Bu}-t}\right)$ and $\left.\mathrm{H}_{2}{ }^{\mathrm{dcp}} \mathrm{N}_{2} \mathrm{P}^{\mathrm{Bu}-t}\right)$ readily undergo amine-elimination reaction with $\left[\mathrm{Fe}\left(\mathrm{N}\left(\mathrm{SiMe}_{3}\right)_{2}\right)_{2}\right]_{2}(0.5$ euiqv. $)$ at room temperature to afford (amido-phosphine-amido)iron(II) complexes $\left[\left(\kappa^{3}-N, N, P-{ }^{\mathrm{Mes}} \mathrm{N}_{2} \mathrm{P}^{\mathrm{Bu}-t}\right) \mathrm{Fe}\left(\mathrm{OEt}_{2}\right)\right](\mathbf{1})$ and $\left[\left(\kappa^{3}-N, N, P_{-}{ }_{-}^{\mathrm{dcp}} \mathrm{N}_{2^{-}}\right.\right.$ $\left.\left.\mathrm{P}^{\mathrm{Bu}-t}\right) \mathrm{Fe}\left(\mathrm{OEt}_{2}\right)\right](2)$ in $49 \%$ and $77 \%$ isolated yields, respectively (Scheme 2). Complexes $\mathbf{1}$ and $\mathbf{2}$ are sensitive to air and moisture. They are soluble in diethyl ether, toluene and tetrahydrofuran, and have been characterized by ${ }^{1} \mathrm{H}$ NMR, solution magnetic moment measurement, ${ }^{57} \mathrm{Fe}$ Mössbauer spectroscopy, as well as elemental analysis. Their measured solution magnetic moments $\left(\mu_{\mathrm{eff}}=4.7(1) \mu_{\mathrm{B}}\right.$ and 5.0(1) $\mu_{\mathrm{B}}$ in $\mathrm{C}_{6} \mathrm{D}_{6}$ at room temperature for $\mathbf{1}$ and $\mathbf{2}$, respectively) and ${ }^{57} \mathrm{Fe}$ Mössbauer spectroscopic data (isomer shift $\delta=0.75 \mathrm{~mm} / \mathrm{s}$, quadrupole splitting $\left|\Delta E_{\mathrm{Q}}\right|=1.19 \mathrm{~mm} / \mathrm{s}$ for $\mathbf{1} ; \delta=0.82$ $\mathrm{mm} / \mathrm{s},\left|\Delta E_{\mathrm{Q}}\right|=2.40 \mathrm{~mm} / \mathrm{s}$ for 2 ) are indicative of their high-spin iron(II) nature $(S=2)$. The difference in the ${ }^{57} \mathrm{Fe}$ Mössbauer data of $\mathbf{1}$ and $\mathbf{2}$ should be caused by their different $N$-aryl substituents.

The molecular structure of $\mathbf{2}$ has been confirmed by single-crystal X-ray diffraction study. As shown in Figure 1, the amido-phosphine-amido ligand in $\mathbf{2}$ is coordinating with the iron center in a tripodal conformation, being similar to the reported (amido-phosphine-amido)iron(II) complex $\left[\left(\kappa^{3}-N, N, P_{-}{ }^{\mathrm{Mes}} \mathrm{N}_{2} \mathrm{P}^{\mathrm{Ph}}\right) \mathrm{Fe}\left(\mathrm{OEt}_{2}\right)\right] \cdot{ }^{[24]}$ Notably, while the $\mathrm{Fe}-$ $\mathrm{N}$ distances in $\mathbf{2}$ are comparable to those of their congeners in $\left[\left(\kappa^{3}-N, N, P-{ }^{\mathrm{Mes}} \mathrm{N}_{2} \mathrm{P}^{\mathrm{Ph}}\right) \mathrm{Fe}\left(\mathrm{OEt}_{2}\right)\right]^{[24]}$, its $\mathrm{Fe}-\mathrm{P}$ bond with a distance of $0.24116(5) \mathrm{nm}$ is longer than that in $\left[\left(\kappa^{3}-N, N, P-{ }^{\mathrm{Mes}} \mathrm{N}_{2} \mathrm{P}^{\mathrm{Ph}}\right) \mathrm{Fe}\left(\mathrm{OEt}_{2}\right)\right]^{[24]}[0.2367(1) \mathrm{nm}]$. The long $\mathrm{Fe}-\mathrm{P}$ distance in 2 reflects the influence of the steric demanding nature of tert-butyl versus phenyl group. Another worth mentioning structural feature of $\mathbf{2}$ is its $\mathrm{Fe}-\mathrm{Cl}(3)$ distance of $0.2845 \mathrm{~nm}$, which lies between the sum of the two van der Waals radii $(0.307 \mathrm{~nm})$ and the $\mathrm{Fe}(\mathrm{II})-\mathrm{Cl}$ distance in the five-coordinate (bis(imino)pyridine)iron(II) chloride complex $\left[(\mathrm{PDI}) \mathrm{FeCl}_{2}\right]^{[25]}(0.2301 \mathrm{~nm})$, indicating weaker interaction between the two atoms.

\subsection{Reactions of $\mathbf{1}$ and $\mathbf{2}$ with diazoalkanes}

With the new (amido-phosphine-amido)iron (II) compounds $\mathbf{1}$ and $\mathbf{2}$ in hand, we further studied their reactions with ( $p$-tolyl $)_{2} \mathrm{CN}_{2}, \mathrm{PhC}\left(\mathrm{N}_{2}\right) \mathrm{CO}_{2} \mathrm{Et}$, and $\mathrm{DmpC}\left(\mathrm{N}_{2}\right) \mathrm{H}$ $(\mathrm{Dmp}=2,6$-dimesitylphenyl), which were found to give

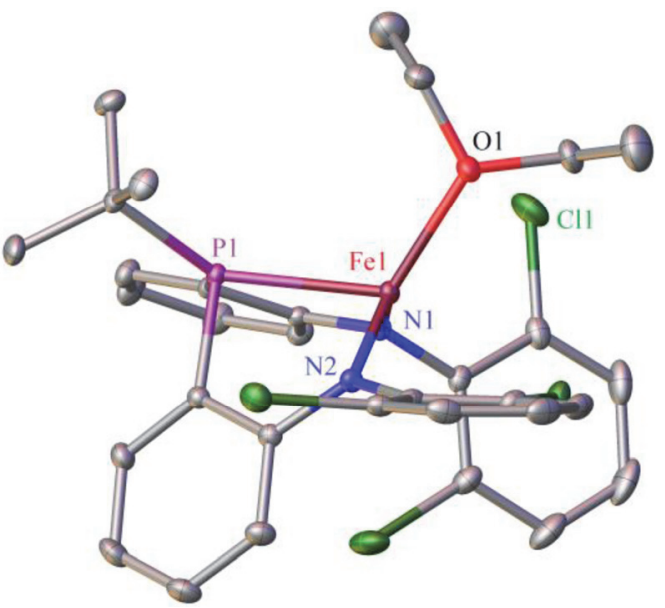

Figure 1 Molecular structure of $\mathbf{2}$ (hydrogen atoms were omitted)

Selected distances $(\mathrm{nm})$ and angles $\left({ }^{\circ}\right)$ : $\mathrm{Fe} 1-\mathrm{N} 1,0.19877(14) ; \mathrm{Fe} 1-\mathrm{N} 2$, 0.19926(14); $\mathrm{Fe} 1-\mathrm{P} 1,0.24116(5) ; \mathrm{Fe} 1-\mathrm{Cl} 1,0.2845 ; \mathrm{Fe} 1-\mathrm{O} 1$, 0.20626(13); $\mathrm{N} 1-\mathrm{Fe} 1-\mathrm{N} 2,123.31(6) ; \mathrm{N} 1-\mathrm{Fe} 1-\mathrm{P} 1,80.99(4) ; \mathrm{N} 1-$ $\mathrm{Fe} 1-\mathrm{O} 1,113.78(6) ; \mathrm{N} 2-\mathrm{Fe} 1-\mathrm{P} 1,84.25(4) ; \mathrm{N} 2-\mathrm{Fe} 1-\mathrm{O} 1,121.62(6)$; $\mathrm{P} 1-\mathrm{Fe} 1-\mathrm{O} 1,117.17(4) ; \mathrm{P} 1-\mathrm{Fe} 1-\mathrm{Cl1}, 153.00$

different outcomes.

\subsection{Reaction of 1 with $(p \text {-Tolyl })_{2} \mathrm{CN}_{2}$}

The interaction of 1 with ( $p$-tolyl $)_{2} \mathrm{CN}_{2}$ (1 equiv.) in toluene or THF at room temperature produced a brown solution without $\mathrm{N}_{2}$-evolution. Further workup and recrystallization led to the isolation of a diazoalkane complex $\left[\left(\kappa^{3}-N, N, P-{ }^{\mathrm{Mes}} \mathrm{N}_{2} \mathrm{P}^{\mathrm{Bu}-t}\right) \mathrm{Fe}\left(\eta^{2}-N, N-(p \text {-tolyl })_{2} \mathrm{CN}_{2}\right)\right](3)$ in $56 \%$ yield (Scheme 3 ). The attainment of $\mathbf{3}$ differs from the formation of ylide complex in the reaction of $\left[\left(\kappa^{3}-N, N, P\right.\right.$ $\left.{ }^{\text {dfp }} \mathrm{N}_{2} \mathrm{P}^{\mathrm{Ph}}\right) \mathrm{Fe}(\mathrm{THF})_{2}$ ] with $(p \text {-tolyl })_{2} \mathrm{CN}_{2}$, which demonstrates the effect of the ligand subsituents on the stability of the iron diazoalkane complexes. The attempts to access alkylidene iron species by thermolysis of $\mathbf{3}$ in benzene gave an intractable mixture.

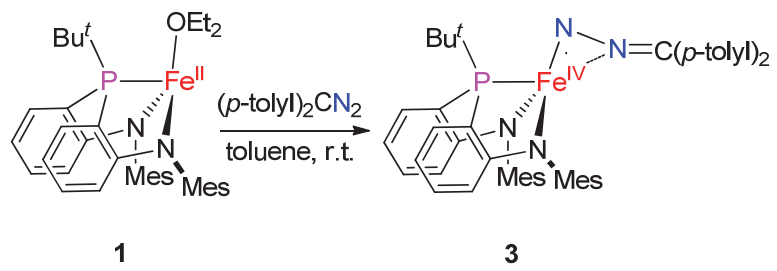

Scheme 3 Reaction of 1 with $(p \text {-tolyl })_{2} \mathrm{CN}_{2}$

Complex 3 has been characterized by ${ }^{1} \mathrm{H}$ NMR, ${ }^{13} \mathrm{C}$ NMR, and ${ }^{31} \mathrm{P}$ NMR spectroscopies, ${ }^{57} \mathrm{Fe}$ Mössbauer spectroscopy, infrared spectroscopy, single-crystal X-ray diffraction, as well as elemental analysis. The molecular structure of $\mathbf{3}$ established by X-ray diffraction study revealed a side-on coordination mode of the diazoalkane ligand that has the $\mathrm{Fe}-\mathrm{N} 2$ and $\mathrm{Fe}-\mathrm{N} 1$ distances of $0.17524(11)$ and $0.19601(11) \mathrm{nm}$, respectively (Figure 2). The Fe1-N2 distance is obviously shorter than its congener in the side-on diazoalkane complexes [(PDI)Fe $\left(\eta^{2}-N, N-\right.$ $\left.\left.\mathrm{N}_{2} \mathrm{CPh}_{2}\right)\right]^{[22]}(0.1903 \mathrm{~nm})$ and $\left[\mathrm{L}^{\mathrm{Bu}-t} \mathrm{Fe}\left(\eta^{2}-N, N-\mathrm{N}_{2} \mathrm{CPh}_{2}\right)-\right.$ $\left.\mathrm{K}\left(\mathrm{OEt}_{2}\right)\right]_{2}{ }^{[20]}[0.1839(2) \mathrm{nm}]$, and is more close to the 
$\mathrm{Fe}-\mathrm{N}$ distances of the end-on diazoalkane complexes $\left[(\mathrm{IPr}) \mathrm{Fe}\left(\mathrm{NAr}{ }^{\text {Trip }}\right)\left(\eta^{1}-\mathrm{N}_{2} \mathrm{C}(\text { tolyl }-p)_{2}\right)\right]^{[26]} \quad[0.1727(2) \mathrm{nm}]$, $\left[(\right.$ tpe $\left.) \mathrm{Fe}\left(\eta^{1}-\mathrm{N}_{2} \mathrm{CPh}_{2}\right)\right]\left[\mathrm{Li}(\mathrm{THF})_{4}\right]^{[19]}[0.1781(9) \mathrm{nm}]$, and $\left[\mathrm{L}^{\mathrm{Bu}-t} \mathrm{Fe}\left(\eta^{1}-\mathrm{N}_{2} \mathrm{CPh}_{2}\right)\right]^{[20]}[0.1752(1) \mathrm{nm}]$, reaching the long end of the $\mathrm{Fe}-\mathrm{N}$ distances of terminal iron imido complexes. ${ }^{[26]}$ The $\mathrm{N}-\mathrm{N}$ and $\mathrm{N}-\mathrm{C}$ bonds of the side-on diazoalkane ligand with the distances of 0.13292(16) and $0.13054(17) \mathrm{nm}$, respectively, are comparable to those of the middle transition-metal complexes that feature dianionic diazo ligands, e.g. $\left[\mathrm{Mo}\left(\mathrm{OBu}^{t}\right)_{4}\left(\mathrm{NNPh}_{2}\right)\right]^{[27]}$ and $[\mathrm{Cr}(\mathrm{OSi}-$ $\left.\left.\mathrm{Bu}_{3}^{t}\right)_{2}\left(\mathrm{NNCPh}_{2}\right)_{2}\right] .{ }^{[28]}$ As compared to the diazo radical ligands, the $\mathrm{N}-\mathrm{N}$ and $\mathrm{N}-\mathrm{C}$ bonds in $\mathbf{3}$ are longer and shorter, respectively, than their counterparts in $\left[(\mathrm{tpe}) \mathrm{Fe}\left(\eta^{1}-\right.\right.$ $\left.\left.\mathrm{N}_{2} \mathrm{CPh}_{2}\right)\right]\left[\mathrm{Li}(\mathrm{THF})_{4}\right]^{[19]}$ and $\left[\mathrm{L}^{\mathrm{Bu}-t} \mathrm{Co}\left(\eta^{1}-\mathrm{N}_{2} \mathrm{CPh}_{2}\right)\right] .{ }^{[20]}$ The characteristic bond distances of the diazo ligand in $\mathbf{3}$, in addition with the short $\mathrm{Fe}-\mathrm{N}$ (amido) [0.18571(11) and $0.18559(11) \mathrm{nm}]$ and $\mathrm{Fe}-\mathrm{P}$ [0.21628(4) $\mathrm{nm}]$ distances seem to agree with the assignment of $\mathbf{3}$ as an iron(IV) complex having a dianionic diazo ligand $\left[\eta^{2}-N, N-(p \text {-tolyl })_{2}-\right.$ $\left.\left.\mathrm{CN}_{2}\right)\right]^{2-}$.

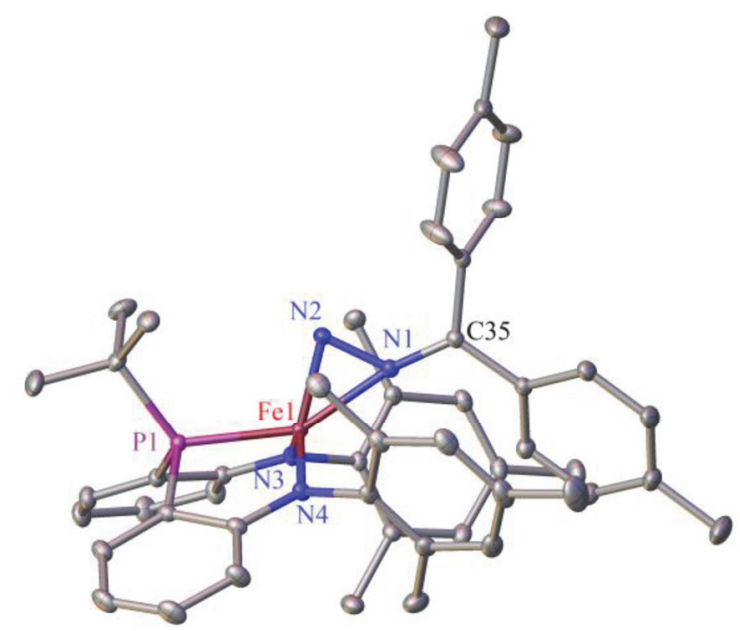

Figure 2 Molecular structure of complex 3 (hydrogen atoms were omitted)

Selected distances $(\mathrm{nm})$ and angles $\left({ }^{\circ}\right)$ : Fe1-P1, 0.21628(4); Fe1-N3, 0.18571(11); Fe1-N4, 0.18559(11); Fe1-N1, 0.19601(11); Fe1-N2, 0.17524(11); $\mathrm{N} 3-\mathrm{Fe} 1-\mathrm{P} 1,85.38(3) ; \mathrm{N} 4-\mathrm{Fe} 1-\mathrm{P} 1,85.93(4) ; \mathrm{N} 4-$ $\mathrm{Fe} 1-\mathrm{N} 3,128.91(5)$

Theoretical studies on $\mathbf{3}$ have further corroborated the assignment of $\mathbf{3}$ as an iron(IV) complex having a dianionic diazo ligand. Single point energy calculations at the B3LYP/TZVP/SVP level of theory based on the molecular structure of 3 established by X-ray diffraction study indicate that the complex at its $S=0$ spin state is 55.76 and 128.41 $\mathrm{kJ} / \mathrm{mol}$, respectively, lower in energy than those of the $S=1$ and $S=2$ spin states. Localized orbital analysis on the $S=0$ state revealed the presence of both $\sigma$ - and $\pi$-type interactions between the iron center and the terminal nitrogen atom of the diazo ligand (Figure 3). Meanwhile, the $\mathrm{N}-\mathrm{N}$ and $\mathrm{N}-\mathrm{C}$ bonds of the diazo ligand are found single- and double-bond in character, respectively (Figure 4). The composition of the frontier orbitals (Figure 3 ) points to an electronic configuration of $\left(d_{x y}\right)^{2}\left(d_{x z}\right)^{2}\left(d_{x-y^{2}}^{2}\right)^{0}\left(d_{z}^{2}\right)^{0}\left(d_{y z}\right)^{0}$ for the covalent iron(IV) complex 3. Being supportive to this assignment, complex 3 is diamagnetic and its zero-field ${ }^{57} \mathrm{Fe}$ Mössbauer data measured at $80 \mathrm{~K}(\delta=0.02 \mathrm{~mm} / \mathrm{s}$ and $\left.\left|\Delta E_{\mathrm{Q}}\right|=2.98 \mathrm{~mm} / \mathrm{s}\right)$ is in reasonable agreement with those of the calculated ones $\left(\delta=-0.08 \mathrm{~mm} / \mathrm{s}\right.$ and $\Delta E_{\mathrm{Q}}=3.61$ $\mathrm{mm} / \mathrm{s}$ ).

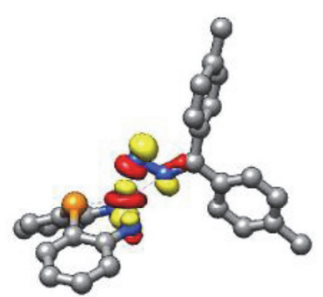

$0 e^{-}$, Fe3d $51 \%$, N2p 29\%

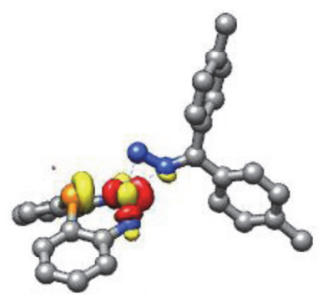

$0 \mathrm{e}^{-}, \mathrm{Fe} 3 \mathrm{~d} 57 \%$, P3p 15\%

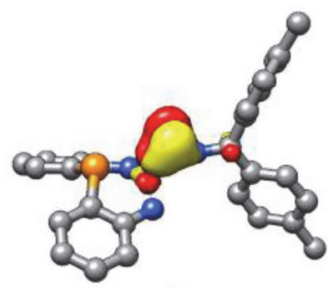

$2 e^{-}$, Fe3d $30 \%$, N2p $57 \%$

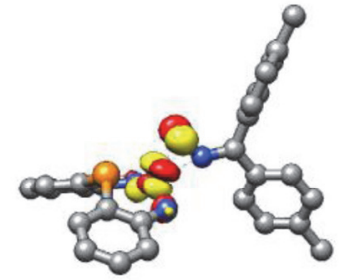

$0 e^{-}$, Fe3d $53 \%$, N2p 23\%

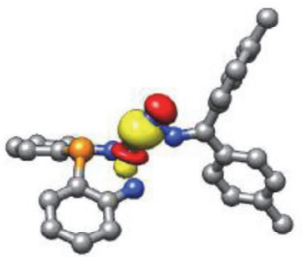

$2 e^{-}$, Fe3d $45 \%$, N2p 55\%

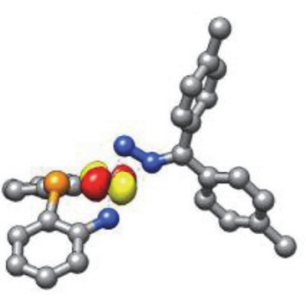

$2 e^{-}$, Fe3d $97 \%$

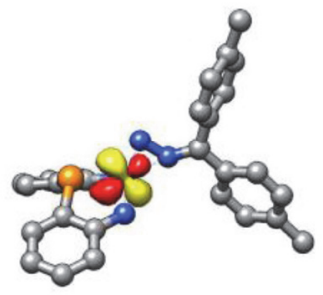

$2 e^{-}$, Fe3d $97 \%$

Figure 3 Selected localized orbitals for 3 (hydrogen atoms and substituents on ligands were omitted)

\subsection{Reaction of 1 with $\mathrm{PhC}\left(\mathrm{N}_{2}\right) \mathrm{CO}_{2} \mathrm{Et}$}

Complex 1 can also readily react with the diazo compound $\mathrm{PhC}\left(\mathrm{N}_{2}\right) \mathrm{CO}_{2}$ Et at room temperature, producing the diazo iron complex $\left[\left(\kappa^{3}-N, N, P-{ }^{\mathrm{Mes}} \mathrm{N}_{2} \mathrm{P}^{\mathrm{Bu}-t}\right) \mathrm{Fe}\left(\kappa^{2}-N, O-\right.\right.$ $\left.\left.\mathrm{PhC}\left(\mathrm{N}_{2}\right) \mathrm{CO}_{2} \mathrm{Et}\right)\right]$ (4) in $60 \%$ isolated yield (Scheme 4). As isolated, complex 4 presents a brown-green crystalline solid, and is sensitive to air and water. Its solution magnetic moment $\left(\mu_{\text {eff }}=3.2(1) \mu_{\mathrm{B}}\right.$ in $\left.\mathrm{C}_{6} \mathrm{D}_{6}\right)$ indicates an $S=1$ ground state. The zero-field ${ }^{57} \mathrm{Fe}$ Mössbauer spectrum of 4 measured at $80 \mathrm{~K}$ features one quadrupole doublet with $\delta=0.25$ $\mathrm{mm} / \mathrm{s}$ and $\left|\Delta E_{\mathrm{Q}}\right|=2.55 \mathrm{~mm} / \mathrm{s}$. The Mössbauer data are apparently different from those of $\mathbf{1}$ or $\mathbf{3}$, hinting at the distinct electronic nature of their iron centers (Figure 5). The 

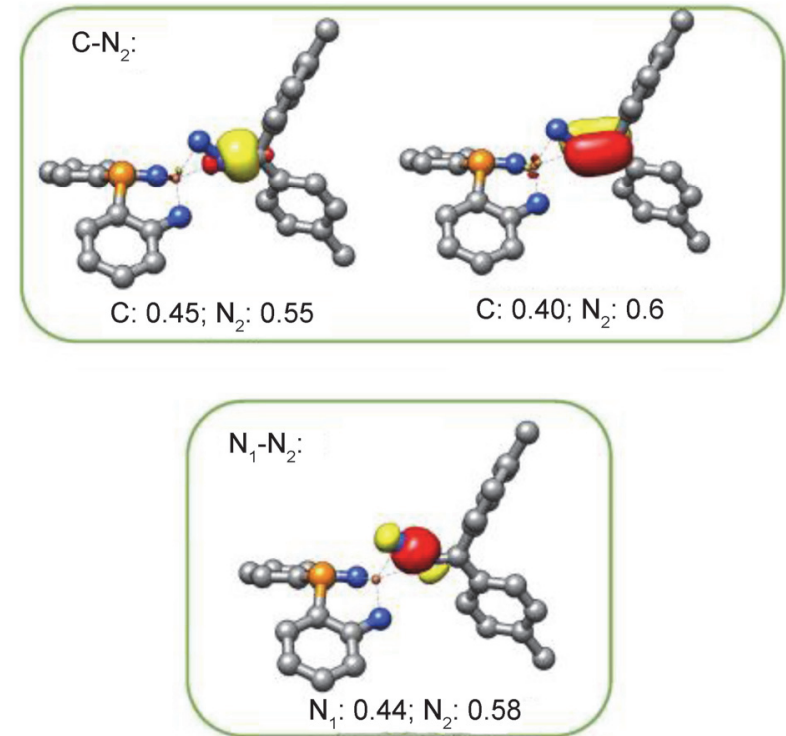

Figure 4 Selected localized orbitals for the $\mathrm{N}-\mathrm{N}$ and $\mathrm{N}-\mathrm{C}$ bonds in 3 (hydrogen atoms and substituents on ligands were omitted)

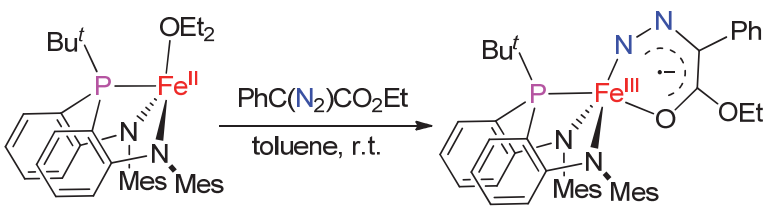

1

4

Scheme 4 Reaction of 1 with $\mathrm{PhC}\left(\mathrm{N}_{2}\right) \mathrm{CO}_{2} \mathrm{Et}$

attempts to access alkylidene iron complexes by thermolysis of 4 in benzene were unsuccessful.

The solid-state structure of $\mathbf{4}$, determined by X-ray crystallography, revealed that the diazo ligand is coordinating to the iron center via its terminal nitrogen atom and carbonyl oxygen atom, forming a planar six-membered chelating ring (Figure 6). Thus, complex 4 is among the rare examples of metal complexes featuring chelating diazo-ketone/ester ligands after $\left[\mathrm{RhCl}\left(\mathrm{PPr}_{3}^{i}\right)_{2}\left(\kappa^{2}-N, O-\mathrm{Me}_{2}-\right.\right.$ $\left.\left.\mathrm{CHCH}_{2} \mathrm{C}(\mathrm{O}) \mathrm{C}(\mathrm{Ph}) \mathrm{N}_{2}\right)\right]^{[15]}$ and $\left[\left(\mathrm{Bu}_{2}^{t} \mathrm{P}\left(\mathrm{NSiMe}_{3}\right)_{2}\right) \mathrm{Cu}\left(\kappa^{2}-\right.\right.$ $\left.\left.N, O-\mathrm{O}\left(\mathrm{N}_{2}\right) \mathrm{C}_{2}\left(\mathrm{C}_{12} \mathrm{H}_{8}\right)\right)\right] .{ }^{[29]}$ The distances of $\mathrm{Fe} 1-\mathrm{N} 3$ and $\mathrm{Fe} 1-\mathrm{O} 1$ bonds in 4 [0.1873(2) and 0.19696(17) nm, respectively] are typical as single bonds. The N3-N4, N4C36, C36-C35, C35-O1 distances [0.1212(3), 0.1353(3), 0.1414 and $0.1248 \mathrm{~nm}$, respectively] deviate from those of the single and double bonds, indicative of electron-delocalization within the chelating ring.

Density functional theory (DFT) calculations have been used to further probe the electronic structure of 4 . The calculation study at the B3LYP/TZVP/SVP level of theory indicates that the complex has an $S=1$ ground spin-state that lies lower in energy than the $S=0$ and $S=2$ spin states by 70.27 and $57.23 \mathrm{~kJ} / \mathrm{mol}$, respectively. The calculated $S=1$ ground spin-state is consistent with that referring from the solution magnetic susceptibility of 4 . At the ground spin state, maximal alignment of the $\alpha$ - and $\beta$-spins of the molecular orbital diagram indicated significant spin polariza-

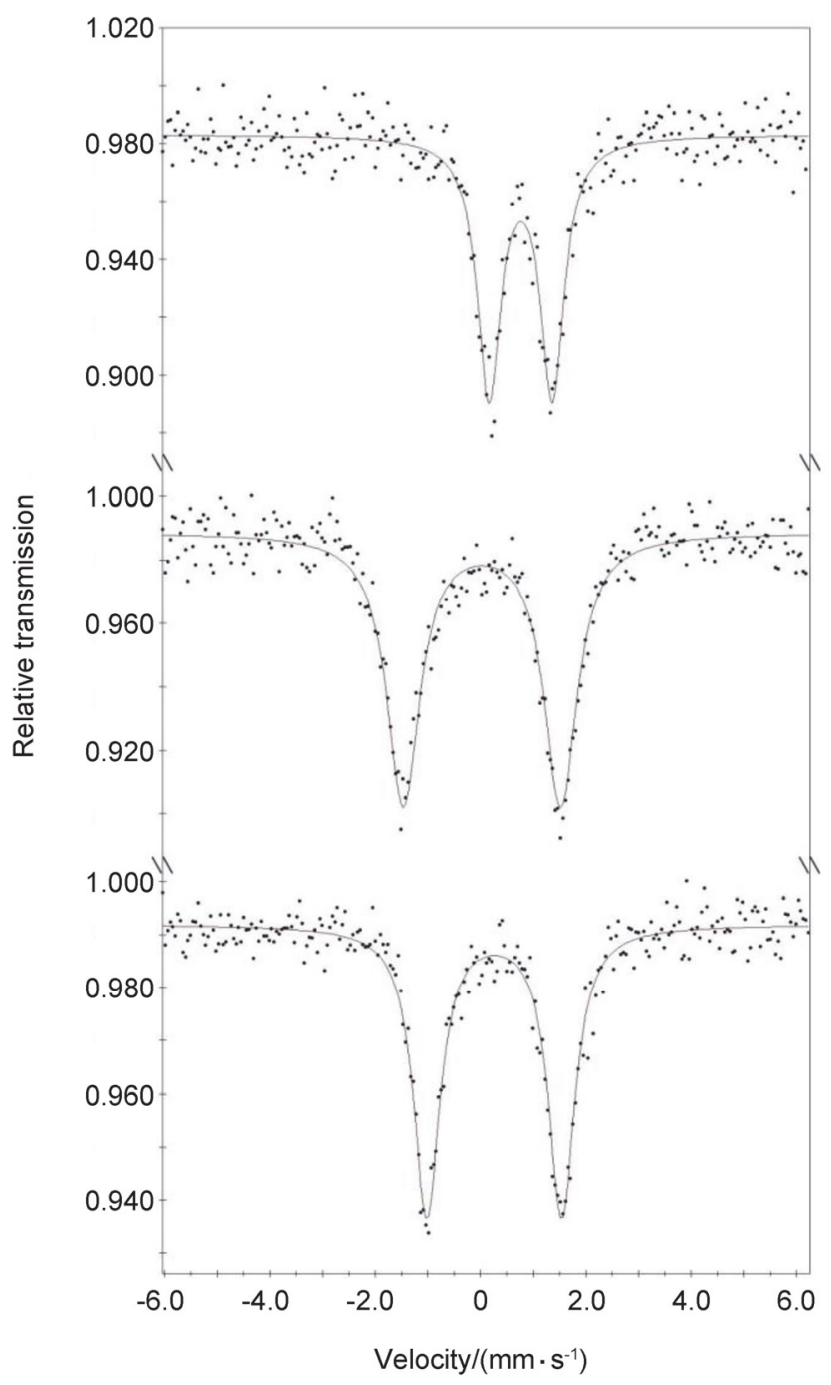

Figure $5{ }^{57} \mathrm{Fe}$ Mössbauer spectra (80 K, zero-field) of 1 (top), 3 (middle), and $\mathbf{4}$ (bottom)

The data (dots) and best fits (solid line) are shown. The fitting data are compiled in Table 1

Table 1 Zero-Field ${ }^{57} \mathrm{Fe}$ Mössbauer spectroscopic data of $\mathbf{1} \sim \mathbf{5}$ measured at $80 \mathrm{~K}$

\begin{tabular}{ccc}
\hline Complex & $\delta /\left(\mathrm{mm} \cdot \mathrm{s}^{-1}\right)$ & $\left|\Delta E_{\mathrm{Q}}\right| /\left(\mathrm{mm} \cdot \mathrm{s}^{-1}\right)$ \\
\hline $\mathbf{1}$ & 0.75 & 1.19 \\
$\mathbf{2}$ & 0.82 & 2.40 \\
$\mathbf{3}$ & 0.02 & 2.98 \\
$\mathbf{4}$ & 0.25 & 2.55 \\
$\mathbf{5}$ & 0.70 & 1.24 \\
\hline
\end{tabular}

tion, where one electron pair has an orbital overlap of $76 \%$ between an iron $3 \mathrm{~d}$ orbital and the $\pi$-orbital of the $\mathrm{N}-\mathrm{N}$ moiety of the diazo ligand (Figure 7), indicating an electronic structure of an intermediate spin iron(III) $\left(S_{\mathrm{Fe}}=3 / 2\right)$ antiferromagnetically coupled with a ligand-based radical $\left(S_{\text {diazo }}=1 / 2\right)$ for 4 . In line with this assignment, $\mathrm{Fe}-\mathrm{N}$ [0.19258(19) and 0.19382(19) nm] and $\mathrm{Fe}-\mathrm{P}[0.22431(8)$ $\mathrm{nm}$ ] distances between the amido-phosphine-amido ligand and the iron center are found to be locating between those of $\mathbf{1}$ and $\mathbf{3}$ that have high-spin iron(II) and low-spin iron(IV) 


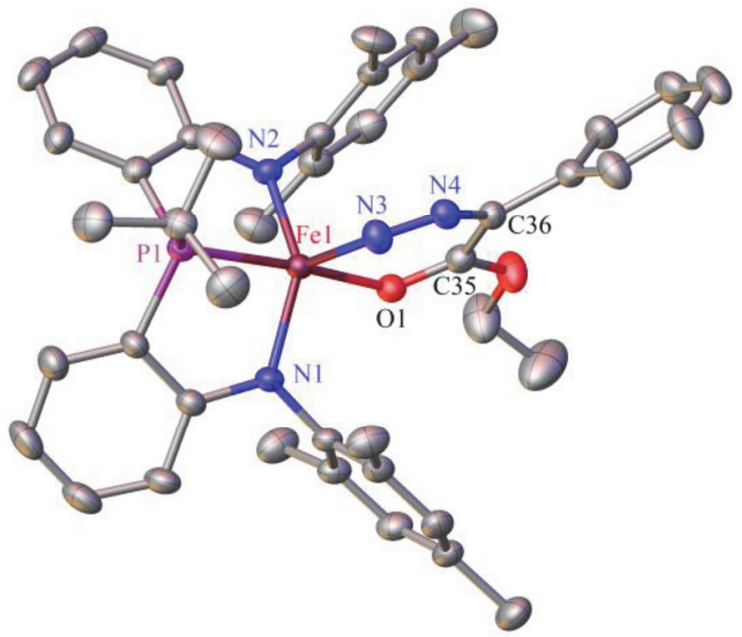

Figure 6 Molecular structure of 4 (hydrogen atoms were omitted)

Selected distances $(\mathrm{nm})$ and angles $\left({ }^{\circ}\right)$ : $\mathrm{Fe} 1-\mathrm{P} 1,0.22431(8) ; \mathrm{Fe} 1-\mathrm{O} 1$, 0.19696(17); Fe1-N1, 0.19258(19); Fe1-N2, 0.19382(19); Fe1-N3, 0.1874(2); $\mathrm{O} 1-\mathrm{Fe} 1-\mathrm{P} 1,169.88(5) ; \mathrm{N} 1-\mathrm{Fe} 1-\mathrm{P} 1,83.23(6) ; \mathrm{N} 1-$ $\mathrm{Fe} 1-\mathrm{O} 1,93.65(7) ; \mathrm{N} 1-\mathrm{Fe} 1-\mathrm{N} 2,138.58(9)$; N2-Fe1-P1, 83.55(6); $\mathrm{N} 2-\mathrm{Fe} 1-\mathrm{O} 1,92.61(8)$

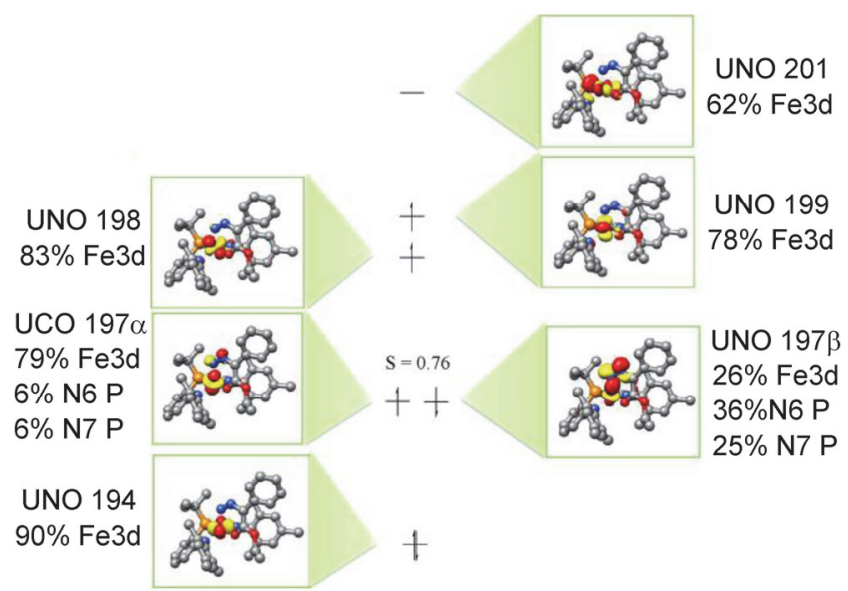

Figure 7 Frontier molecular orbital diagram for $\mathbf{4}$ at an $S=1$ spin-state

centers, respectively.

\subsection{Reactions of $\mathbf{2}$ with diazo compounds}

The amido-posphine-amido ligand in $\left[\left(\kappa^{3}-N, N, P-{ }^{\mathrm{dcp}} \mathrm{N}_{2}-\right.\right.$ $\left.\left.\mathrm{P}^{\mathrm{Bu}-\mathrm{t}}\right) \mathrm{Fe}\left(\mathrm{OEt}_{2}\right)\right]$ (2) has 2,6-dichlorophenyl as its $N$-substituents that should have different steric and electronic character when compared to the mesityl groups in $\mathbf{1}$. Examining the reaction of $\mathbf{2}$ with $(p \text {-tolyl })_{2} \mathrm{CN}_{2}$ revealed the capability of the iron complex in catalzying the conversion of $(p \text {-tolyl })_{2} \mathrm{CN}_{2}$ to $(p \text {-tolyl })_{2} \mathrm{C}=\mathrm{NN}=\mathrm{C}(\text { tolyl }-p)_{2}$, wherein the reaction in an $1: 1$ ratio produced the azine along with the majority of 2 remained unreactive according to ${ }^{1} \mathrm{H}$ NMR analysis. With a catalyst loading of $5 \mathrm{~mol} \% 2$, the reaction at room temperature in $\mathrm{C}_{6} \mathrm{D}_{6}$ for $1 \mathrm{~h}$ produced ( $p$-tolyl) $)_{2} \mathrm{C}=\mathrm{NN}=\mathrm{C}$ (tolyl $\left.-p\right)_{2}$ in $73 \%$ NMR yield (Scheme 5). The result hints that the iron(IV) alkylidene intermediate $\left(\kappa^{3}-N, N, P_{-}{ }^{\mathrm{dcp}} \mathrm{N}_{2} \mathrm{P}^{\mathrm{Bu}-t}\right) \mathrm{Fe}\left(\mathrm{C}(\text { tolyl }-p)_{2}\right)$ might be formed during the reaction course. This intermediate, however, might be highly active and susceptible to the attack by
( $p$-tolyl $)_{2} \mathrm{CN}_{2}$, leading to the formation of the azine $(p \text {-tolyl })_{2} \mathrm{C}=\mathrm{NN}=\mathrm{C}(\text { tolyl }-p)_{2}$.

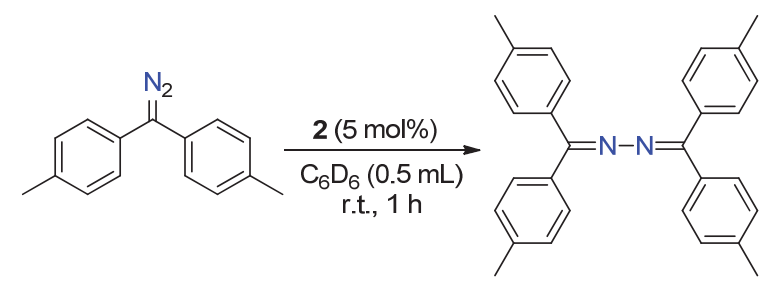

Scheme 5 Conversion of ( $p$-tolyl $)_{2} \mathrm{CN}_{2}$ to its azine catalyzed by 2

The other diazo compound was examined in the reactions with 2 is $\operatorname{DmpC}\left(\mathrm{N}_{2}\right) \mathrm{H}(\mathrm{Dmp}=2$,6-dimesityphenyl) that bears a sterically hindered Dmp group. No reaction took place when 2 was treated with $\operatorname{DmpC}\left(\mathrm{N}_{2}\right) \mathrm{H}$ in toluene at room temperature. Elevating temperature to $50{ }^{\circ} \mathrm{C}$ could lead to the occurence of the reaction. Further workup on the reaction mxiture led to the isolation of the diamido-phosphine ylide iron(II) complex $\left[\left(\kappa^{3}-N, N, C-{ }^{\text {dcp }} \mathrm{N}_{2}-\mathrm{P}^{\mathrm{Bu}-t} \mathrm{C}^{\mathrm{H}, \mathrm{Dmp}}\right)\right.$ $\mathrm{Fe}](\mathbf{5})$ in $70 \%$ yield (Scheme 6 ). Complex $\mathbf{5}$ has been fully characterized by various spectrsocopic methods, and its moelcular structure was confirmed by single-crystal X-ray diffraction study (Figure 8). The formation of 5 implies the readiness of the mono-substitued alkylidenemetal species $\left(\kappa^{3}-N, N, P-{ }^{\mathrm{dcp}} \mathrm{N}_{2} \mathrm{P}^{\mathrm{Bu}-t}\right) \mathrm{Fe}[\mathrm{CH}(\mathrm{Dmp})]$ to undergo migratory insertion reaction in spite of the presence of the bulky substituents on the phosphine and alkylidene moieties.

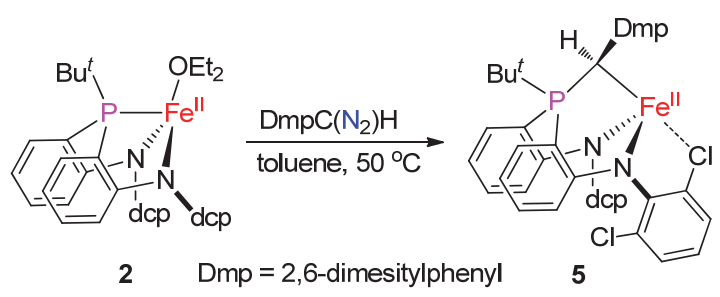

Scheme 6 Reaction of 2 with $\operatorname{DmpC}\left(\mathrm{N}_{2}\right) \mathrm{H}$

\section{Conclusions}

Two new high-spin iron(II) complexes supported by tripodal amido-phosphine-amido ligands $\left[\left(\kappa^{3}-N, N, P\right.\right.$ $\left.\left.{ }^{\text {Mes }} \mathrm{N}_{2} \mathrm{P}^{\mathrm{Bu}-t}\right) \mathrm{Fe}\left(\mathrm{OEt}_{2}\right)\right]$ (1) and $\left[\left(\kappa^{3}-N, N, P{ }_{-}{ }^{\mathrm{dcp}} \mathrm{N}_{2} \mathrm{P}^{\mathrm{Bu}-t}\right)-\right.$ $\left.\mathrm{Fe}\left(\mathrm{OEt}_{2}\right)\right]$ (2) were synthesized, and their reactions with diazoalkane compounds were examined. Complex 1 can react with the diazo compounds ( $p$-tolyl $)_{2} \mathrm{CN}_{2}$ and $\mathrm{PhC}$ $\left(\mathrm{N}_{2}\right) \mathrm{CO}_{2} \mathrm{Et}$ to form the iron diazo complexes [ $\left(\kappa^{3}-N, N, P-\right.$ $\left.\left.{ }^{\mathrm{Mes}} \mathrm{N}_{2} \mathrm{P}^{\mathrm{Bu}-t}\right) \mathrm{Fe}\left(\eta^{2}-N, N-(p \text {-tolyl })_{2} \mathrm{CN}_{2}\right)\right](3)$ and $\left[\left(\kappa^{3}-N, N, P\right.\right.$ $\left.\left.{ }^{\mathrm{Mes}} \mathrm{N}_{2} \mathrm{P}^{\mathrm{Bu}-}\right) \mathrm{Fe}\left(\kappa^{2}-N, O-\mathrm{PhC}\left(\mathrm{N}_{2}\right) \mathrm{CO}_{2} \mathrm{Et}\right)\right]$ (4). Spectroscopic characterization in combination with DFT studies suggest that 3 is a low-spin iron(IV) complex featuring a dianionic diazo ligand $\left.\left[\eta^{2}-(p \text {-tolyl })_{2} \mathrm{CN}_{2}\right)\right]^{2-}$, whereas 4 can be viewed as an intermediate iron(III) complex bearing an antiferromagnetically coupled diazo radical anion $\left[\kappa^{2}-N, O-\right.$ $\left.\left.\mathrm{PhC}\left(\mathrm{N}_{2}\right) \mathrm{CO}_{2} \mathrm{Et}\right)\right]^{\cdot 1-}$. Reactivity studies of 2 revealed its ability in catalyzing the conversion of $(p \text {-tolyl })_{2} \mathrm{CN}_{2}$ to its azine, and its reaction with $\operatorname{DmpC}\left(\mathrm{N}_{2}\right) \mathrm{H}$ was found to 


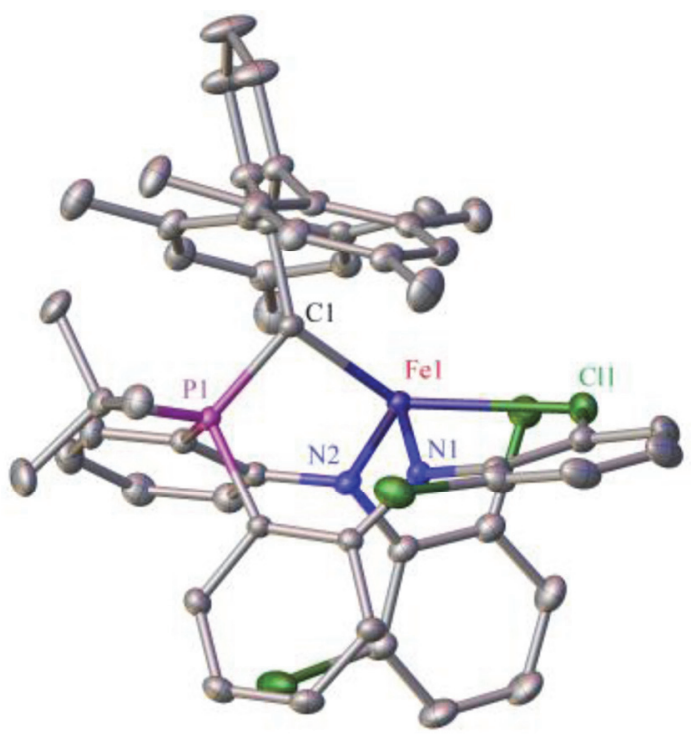

Figure 8 Molecular structure of complex 5 (hydrogen atoms were omitted)

Selected distances $(\mathrm{nm})$ and angles $\left({ }^{\circ}\right)$ : $\mathrm{Fe} 1-\mathrm{C} 11,0.26554(6) ; \mathrm{Fe} 1-\mathrm{P} 1$, $0.28358(6) ; \mathrm{Fe}(1)-\mathrm{N}(1), 0.20286(17) ; \mathrm{Fe} 1-\mathrm{N} 2,0.19863(17) ; \mathrm{Fe} 1-\mathrm{C} 1$ 0.2146(2); $\mathrm{P}(1)-\mathrm{C}(1), 0.1786(2) ; \mathrm{Cl} 1-\mathrm{Fe} 1-\mathrm{P} 1,157.063(19) ; \mathrm{N} 1-$ $\mathrm{Fe} 1-\mathrm{Cl1}$, 75.25(5); N1-Fe1-P1, 82.53(5); N1-Fe1-C1, 88.10(7); $\mathrm{N} 2-\mathrm{Fe} 1-\mathrm{Cl} 1,115.76(5) \mathrm{N} 2-\mathrm{Fe} 1-\mathrm{P} 1,77.93(5) ; \mathrm{N} 2-\mathrm{Fe} 1-\mathrm{N} 1$, 112.567; $\mathrm{N} 2-\mathrm{Fe} 1-\mathrm{C} 1,111.30(7) ; \mathrm{C} 1-\mathrm{Fe} 1-\mathrm{C} 11,132.93(5) ; \mathrm{C} 1-$ $\mathrm{Fe} 1-\mathrm{P} 1,39.01(5)$

produce the high-spin iron(II) ylide complex $\left[\left(\kappa^{3}-N, N, C\right.\right.$ $\left.\left.{ }^{d c p} \mathrm{~N}_{2} \mathrm{P}^{\mathrm{Bu}-t} \mathrm{C}^{\mathrm{H}, \mathrm{Dmp}}\right) \mathrm{Fe}\right](5)$. These results demonstrated that the diversified reactivity of iron(II) species supported by tripodal amido-phosphine-amido scaffolds toward diazoalkenes.

\section{Experimental section}

\subsection{General procedures}

All experiments were performed either under an atmosphere of dry dinitrogen with the rigid exclusion of air and moisture using standard Schlenk techniques or in a glovebox. Organic solvents were dried with a solvent purification system (Innovative Technology) and bubbled with dry $\mathrm{N}_{2}$ gas prior to use. $\left[\mathrm{Fe}\left(\mathrm{N}(\mathrm{TMS})_{2}\right)_{2}\right]_{2}{ }^{[30]}(p \text {-tolyl })_{2} \mathrm{CN}_{2},{ }^{[31]}$ $\operatorname{DmpC}\left(\mathrm{N}_{2}\right) \mathrm{H}^{[32]}$ were synthesized according to literature procedures. All other chemicals were purchased from either Strem or J\&K Chemical Co. and used as received unless otherwise noted. ${ }^{1} \mathrm{H}$ NMR, ${ }^{13} \mathrm{C}$ NMR and ${ }^{31} \mathrm{P}$ NMR spectra were recorded on an Agilent $400 \mathrm{MHz}$ spectrometers. Chemical shifts were reported with references to the residue of the deuterated solvents for proton and carbon chemical shifts, and to external $85 \%$ phosphoric acid solution for phosphorous chemical shifts. For the ${ }^{1} \mathrm{H}$ NMR data, the widths of peaks at their half heights are denoted as $v_{1 / 2}$. Elemental analyses were performed by the Analytical Laboratory of Shanghai Institute of Organic Chemistry (CAS). Magnetic moments were measured by the method originally described by Evans with stock and experimental solutions containing a known amount of $\left(\mathrm{CH}_{3}\right)_{3} \mathrm{SiOSi}\left(\mathrm{CH}_{3}\right)_{3}$ standard. ${ }^{[33]}$ IR spectra were recorded with a NICOLET AVA-
TAR 330 FT-IR spectrophotometer.

\subsection{X-ray structure determination}

Crystals were coated with Paratone- $N$ oil and mounted on a Bruker APEX CCD-based diffractometer equipped with an Oxford low-temperature apparatus. Cell parameters were retrieved with SMART software and refined using SAINT software on all reflections. Data integration was performed with SAINT, which corrected for Lorentz polarization and decay. Absorption corrections were applied using SADABS. ${ }^{[34]}$ Space groups were assigned unambiguously by analysis of symmetry and systematic absences determined by XPREP. All structures were solved and refined using SHELXTL SADABS. ${ }^{[34]}$ Metal and first coordination sphere atoms were located from direct-methods E-maps. Non-hydrogen atoms were found in alternating difference Fourier synthesis and least-squares refinement cycles, and were refined anisotropically during final cycles. The crystal data, and summary of data collection and refinement for the complexes were summarized in Tables S1. CCDC $2006056 \sim 2006059$ contain the supplementary crystallographic data for complexes $\mathbf{2} \sim \mathbf{4}$, and $\mathbf{5} \cdot \mathrm{Et}_{2} \mathrm{O}$. These data can be obtained free of charge from The Cambridge Crystallographic Data Centre via www.ccdc.cam.ac.uk/data request/cif.

\section{3 ${ }^{57} \mathrm{Fe}$ Mössbauer spectroscopy}

All solid samples for ${ }^{57} \mathrm{Fe}$ Mössbauer spectroscopy were run on non-enriched samples of the as-isolated complexes. Each sample was loaded into a Delrin Mössbauer sample cup for measurements and loaded under liquid nitrogen. Low temperature ${ }^{57} \mathrm{Fe}$ Mössbauer measurements were performed using a SeeCo. MS4 Mössbauer spectrometer integrated with a Janis SVT-400T $\mathrm{He} / \mathrm{N}_{2}$ cryostat for measurements at $80 \mathrm{~K}$. Isomer shifts were determined relative to $\alpha$-Fe at $298 \mathrm{~K}$. All Mössbauer spectra were fitted using the program WMoss (SeeCo).

\subsection{Preparation of $\mathrm{H}_{2}\left({ }^{\text {Mes }} \mathrm{N}_{2} \mathrm{P}^{\text {Bu-t } t}\right)$}

To an $\mathrm{Et}_{2} \mathrm{O}(15 \mathrm{~mL})$ solution of $\left(2,4,6-\mathrm{Me}_{3} \mathrm{C}_{6} \mathrm{H}_{2}\right)(2-\mathrm{Br}-$ $\left.\mathrm{C}_{6} \mathrm{H}_{4}\right) \mathrm{NH}(1.45 \mathrm{~g}, 5 \mathrm{mmol})$ was added ${ }^{n} \mathrm{BuLi}\left(2.5 \mathrm{~mol} \cdot \mathrm{L}^{-1}\right.$ in $n$-hexane, $4 \mathrm{~mL}, 10 \mathrm{mmol}$ ) slowly at $-78{ }^{\circ} \mathrm{C}$. The resulting mixture was allowed to warm to room temperature and further stirred for $5 \mathrm{~h}$. To this solution, an $\mathrm{Et}_{2} \mathrm{O}$ solution $(10 \mathrm{~mL})$ of ${ }^{t} \mathrm{BuPCl}_{2}(0.40 \mathrm{~g}, 2.5 \mathrm{mmol})$ was added at $-78{ }^{\circ} \mathrm{C}$. The resulting mixture was allowed to warm to room temperature and further stirred for $48 \mathrm{~h}$. The mixture was then quenched with a saturated aqueous solution of $\mathrm{NaHCO}_{3}$, and extracted with $\mathrm{CH}_{2} \mathrm{Cl}_{2}(50 \mathrm{~mL} \times 3)$. The combined organic phases were washed with a saturated $\mathrm{NaHCO}_{3}$ aqueous solution, brine, and dried over $\mathrm{Na}_{2} \mathrm{SO}_{4}$. After filtration and removal of volatiles, the crude product was purifiedby flash column chromatography [silica gel, $n$-hexanes $/ \mathrm{CH}_{2} \mathrm{Cl}_{2}(V: V=10: 1)$ as elute] to give $\mathrm{H}_{2}\left({ }^{\mathrm{Mes}} \mathrm{N}_{2} \mathrm{P}^{\mathrm{Bu}-t}\right)$ as a white solid $(0.64 \mathrm{~g}, 50 \%$ yield $)$. m.p. $165 \sim 168{ }^{\circ} \mathrm{C} ;{ }^{1} \mathrm{H}$ NMR $\left(400 \mathrm{MHz}, \mathrm{CDCl}_{3}, 293 \mathrm{~K}\right) \delta$ : $7.63 \sim 7.55(\mathrm{~m}, 2 \mathrm{H}), 7.10(\mathrm{dd}, J=11.3,4.0 \mathrm{~Hz}, 2 \mathrm{H}), 6.95(\mathrm{~s}$, $2 \mathrm{H}), 6.83(\mathrm{~s}, 2 \mathrm{H}), 6.77$ (t, $J=7.4 \mathrm{~Hz}, 2 \mathrm{H}), 6.27$ (d, $J=7.6$ 
$\mathrm{Hz}, 2 \mathrm{H}), 6.19 \sim 6.16(\mathrm{~m}, 2 \mathrm{H}), 2.31(\mathrm{~s}, 6 \mathrm{H}), 2.21(\mathrm{~s}, 6 \mathrm{H})$, $1.64(\mathrm{~s}, 6 \mathrm{H}), 1.53(\mathrm{~d}, J=13.7 \mathrm{~Hz}, 9 \mathrm{H}) ;{ }^{13} \mathrm{C} \mathrm{NMR}(101 \mathrm{MHz}$, $\left.\mathrm{CDCl}_{3}, 293 \mathrm{~K}\right) \delta$ : $149.87\left(\mathrm{~d}, J_{\mathrm{C}-\mathrm{P}}=17.8 \mathrm{~Hz}\right), 136.23$, $135.81\left(\mathrm{~d}, J_{\mathrm{C}-\mathrm{P}}=2.0 \mathrm{~Hz}\right), 135.53,135.21,134.21,130.04$, $129.09,118.39\left(\mathrm{~d}, J_{\mathrm{C}-\mathrm{P}}=11.3 \mathrm{~Hz}\right), 117.58,111.80(\mathrm{~d}$, $\left.J_{\mathrm{C}-\mathrm{P}}=2.8 \mathrm{~Hz}\right), 31.69\left(\mathrm{~d}, J_{\mathrm{C}-\mathrm{P}}=9.1 \mathrm{~Hz}\right), 28.80\left(\mathrm{~d}, J_{\mathrm{C}-\mathrm{P}}=\right.$ $13.8 \mathrm{~Hz}$ ), 21.04, 18.40, 17.50; ${ }^{31} \mathrm{P}$ NMR (162 MHz, $\mathrm{CDCl}_{3}$, 293 K) $\delta:-28.42$; IR (film) $v: 3360(\mathrm{w}), 2944(\mathrm{w}), 2917$ (w), 2859 (w), 1585 (m), 1487 (s), 1438 (s), 1275 (m), 1158 (w), 1033 (w), $1011(\mathrm{w}), 854(\mathrm{~m}), 809(\mathrm{~m}), 746(\mathrm{~s}), 683(\mathrm{w})$, $478(\mathrm{~m}) \mathrm{cm}^{-1}$. HRMS (ESI) calcd for $\mathrm{C}_{34} \mathrm{H}_{42} \mathrm{~N}_{2} \mathrm{P}[\mathrm{M}+\mathrm{H}]^{+}$: 509.3080; found 509.3081

\subsection{Preparation of $\mathrm{H}_{2}\left({ }^{\mathrm{dcp}} \mathrm{N}_{2} \mathrm{P}^{\mathrm{Bu}-\mathrm{t}}\right)$}

To an $\mathrm{Et}_{2} \mathrm{O}(40 \mathrm{~mL})$ solution of $\left(2,6-\mathrm{Cl}_{2} \mathrm{C}_{6} \mathrm{H}_{3}\right)(2-\mathrm{Br}-$ $\left.\mathrm{C}_{6} \mathrm{H}_{4}\right) \mathrm{NH}(3.17 \mathrm{~g}, 10.0 \mathrm{mmol})$ was added ${ }^{n} \mathrm{BuLi}(2.5 \mathrm{~mol} / \mathrm{L}$ in $n$-hexane, $8 \mathrm{~mL}, 20 \mathrm{mmol}$ ) slowly at $-78{ }^{\circ} \mathrm{C}$. The resulting mixture was allowed to warm to room temperature and further stirred for $5 \mathrm{~h}$. To this solution, an $\mathrm{Et}_{2} \mathrm{O}$ solution $(10 \mathrm{~mL})$ of ${ }^{t} \mathrm{BuPCl}_{2}(0.80 \mathrm{~g}, 5 \mathrm{mmol})$ was added at $-78{ }^{\circ} \mathrm{C}$. The resulting mixture was allowed to warm to room temperature and further stirred for $48 \mathrm{~h}$. The mixture was then quenched with a saturated aqueous solution of $\mathrm{NaHCO}_{3}$, and extracted with $\mathrm{CH}_{2} \mathrm{Cl}_{2}(50 \mathrm{~mL} \times 3)$. The combined organic phases were washed with a saturated $\mathrm{NaHCO}_{3}$ aqueous solution, brine, and dried over $\mathrm{Na}_{2} \mathrm{SO}_{4}$. After filtration and removal of volatiles, the crude product was purifiedby flash column chromatography [silica gel, $n$-hexanes $/ \mathrm{CH}_{2} \mathrm{Cl}_{2} \quad(V: V=10: 1)$ as elute] to give $\mathrm{H}_{2}\left({ }^{\text {dep }} \mathrm{N}_{2} \mathrm{P}^{\mathrm{Bu}-t}\right)$ as a white solid (1.50 g, 53\% yield). m.p. $220 \sim 222{ }^{\circ} \mathrm{C} ;{ }^{1} \mathrm{H}$ NMR (400 MHz, $\left.\mathrm{CDCl}_{3}, 293 \mathrm{~K}\right) \delta$ : $7.59 \sim 7.49(\mathrm{~m}, 2 \mathrm{H}), 7.39 \sim 7.19(\mathrm{~m}, 4 \mathrm{H}), 7.14(\mathrm{t}, J=7.7$ $\mathrm{Hz}, 2 \mathrm{H}), 7.00$ (t, $J=8.1 \mathrm{~Hz}, 2 \mathrm{H}), 6.89$ (t, $J=7.4 \mathrm{~Hz}, 2 \mathrm{H})$, $6.64(\mathrm{~d}, J=5.9 \mathrm{~Hz}, 2 \mathrm{H}), 6.33(\mathrm{dd}, J=7.6,5.5 \mathrm{~Hz}, 2 \mathrm{H}), 1.46$ $(\mathrm{d}, J=13.6 \mathrm{~Hz}, 9 \mathrm{H}) ;{ }^{13} \mathrm{C} \mathrm{NMR}\left(101 \mathrm{MHz}, \mathrm{CDCl}_{3}, 293 \mathrm{~K}\right) \delta$ : $147.18\left(\mathrm{~d}, J_{\mathrm{C}-\mathrm{P}}=18.4 \mathrm{~Hz}\right), 136.98,136.95,134.22$, $132.31 \sim 131.94(\mathrm{~m}), 129.55,128.70\left(\mathrm{~d}, J_{\mathrm{C}-\mathrm{P}}=30.6 \mathrm{~Hz}\right)$, $125.55,121.65\left(\mathrm{~d}, J_{\mathrm{C}-\mathrm{P}}=13.3 \mathrm{~Hz}\right) 120.22,114.60,31.77(\mathrm{~d}$, $\left.J_{\mathrm{C}-\mathrm{P}}=10.3 \mathrm{~Hz}\right), 28.71\left(\mathrm{~d}, J_{\mathrm{C}-\mathrm{P}}=13.8 \mathrm{~Hz}\right) ;{ }^{31} \mathrm{P}$ NMR $(162$ $\left.\mathrm{MHz}, \mathrm{CDCl}_{3}, 293 \mathrm{~K}\right) \delta$ : -24.43 ; IR (film) $v$ : 3330 (w), 3298 (w), 2957 (w), 2863 (w), 1569 (m), 1493 (m), 1439 (s), $1411(\mathrm{~m}), 1296(\mathrm{~m}), 1277(\mathrm{~m}), 1192(\mathrm{w}), 1156(\mathrm{w})$, 1095 (w), 838 (s), 773 (s), 504 (w) $\mathrm{cm}^{-1}$. HRMS (ESI) calcd for $\mathrm{C}_{28} \mathrm{H}_{26} \mathrm{~N}_{2} \mathrm{PCl}_{4}[\mathrm{M}+\mathrm{H}]^{+}:$561.0582; found 561.0571 .

4.6 Preparation of $\left[\left(k^{3}-N, N, P_{-}{ }^{\text {Mes }} \mathrm{N}_{2} \mathrm{P}^{\mathrm{Bu}-t}\right) \mathrm{Fe}\left(\mathrm{OEt}_{2}\right)\right]$ (1)

To a toluene $(20 \mathrm{~mL})$ solution of $\mathrm{H}_{2}\left({ }^{\mathrm{Mes}} \mathrm{N}_{2} \mathrm{P}^{\mathrm{Bu}-t}\right)(125 \mathrm{mg}$, $0.25 \mathrm{mmol})$ was added $\left[\mathrm{Fe}\left(\mathrm{N}(\mathrm{TMS})_{2}\right)_{2}\right]_{2}(111 \mathrm{mg}, 0.15$ mmol). The resulting mixture was stirred at $50{ }^{\circ} \mathrm{C}$ for $2 \mathrm{~h}$ to afford a red solution. After removal of the solvent under vacuum, the red residue was washed by $n$-hexane $(10 \mathrm{~mL})$ to produce 1 as an orange solid (77 mg, 49\%). m.p. $>163{ }^{\circ} \mathrm{C}$ (dec.); ${ }^{1} \mathrm{H}$ NMR (400MHz, $\left.\mathrm{C}_{6} \mathrm{D}_{6}, 293 \mathrm{~K}\right) \delta$ : 64.08 (very br), $59.64\left(v_{1 / 2}=49 \mathrm{~Hz}\right), 47.72\left(v_{1 / 2}=87 \mathrm{~Hz}\right)$, $39.46\left(v_{1 / 2}=75 \mathrm{~Hz}\right), 37.57\left(v_{1 / 2}=93 \mathrm{~Hz}\right), 29.53\left(v_{1 / 2}=246\right.$ $\mathrm{Hz}), 23.22\left(v_{1 / 2}=51 \mathrm{~Hz}\right), 10.12$ (very br), 6.21 (very br), $3.93\left(v_{1 / 2}=107 \mathrm{~Hz}\right),-37.23\left(v_{1 / 2}=86 \mathrm{~Hz}\right)$; IR (film) $v$ :
2966 (s), 2916 (s), 2864 (m), 1586 (s), 1452 (s), 1431 (s), 1312 (m), 1266 (m), 1201 (m), 1039 (m), 876 (3), 856 (m), $748(\mathrm{~s}) \mathrm{cm}^{-1}$. Magnetic susceptibility $\left(\mathrm{C}_{6} \mathrm{D}_{6}, 293 \mathrm{~K}\right): \mu_{\mathrm{eff}}=$ 4.7(1) $\mu_{\mathrm{B}}$. Anal. calcd for $\mathrm{C}_{38} \mathrm{H}_{49} \mathrm{FeN}_{2} \mathrm{OP}: \mathrm{C} 71.69, \mathrm{H} 7.76, \mathrm{~N}$ 4.40; found C 71.55, H 7.52, N 4.38. ${ }^{57} \mathrm{Fe}$ Mössbauer spectrum (Zero-field, $80 \mathrm{~K}) \delta: 0.75 \mathrm{~mm} / \mathrm{s},\left|\Delta E_{\mathrm{Q}}\right|=1.19 \mathrm{~mm} / \mathrm{s}$.

\subsection{Preparation of $\left[\left(\kappa^{3}-N, N, P_{-}{ }^{d c p} N_{2} P^{B u-t}\right) F e\left(O_{2}\right)\right](2)$}

To a tetrahydrofuran (THF) $(20 \mathrm{~mL})$ solution of $\mathrm{H}_{2}\left({ }^{\mathrm{dcp}} \mathrm{N}_{2}\right.$ $\left.\mathrm{P}^{\mathrm{Bu}-\mathrm{t}}\right)(105 \mathrm{mg}, 0.19 \mathrm{mmol})$ was added $\left[\mathrm{Fe}\left(\mathrm{N}(\mathrm{TMS})_{2}\right)_{2}\right]_{2}$ (106 $\mathrm{mg}, 0.14 \mathrm{mmol})$. The resulting mixture was stirred at room temperature for $2 \mathrm{~h}$ to afford a orange solution. After removal of the solvent under vacuum, the orange residue was washed by $n$-hexane $(10 \mathrm{~mL})$ to produce 2 as an orange solid (100 mg, 77\%). Single-crystals of 2 suitable for X-ray diffraction study were obtained by standing its saturated $\mathrm{Et}_{2} \mathrm{O}$ solution at room temperature via slow evaporation of $\mathrm{Et}_{2} \mathrm{O}$ overnight. m.p. $>201{ }^{\circ} \mathrm{C}$ (dec.); ${ }^{1} \mathrm{H}$ NMR (400 MHz, $\left.\mathrm{C}_{6} \mathrm{D}_{6}, 293 \mathrm{~K}\right) \delta: 41.55\left(v_{1 / 2}=56 \mathrm{~Hz}\right), 36.74\left(v_{1 / 2}=63 \mathrm{~Hz}\right)$, $33.97\left(v_{1 / 2}=95 \mathrm{~Hz}\right), 29.80\left(v_{1 / 2}=179 \mathrm{~Hz}\right), 16.53\left(v_{1 / 2}=41\right.$ $\mathrm{Hz}), 5.17$ (very br), $-8.68\left(v_{1 / 2}=128 \mathrm{~Hz}\right),-27.67\left(v_{1 / 2}=\right.$ $45 \mathrm{~Hz}),-40.58$ (very br), $-42.64\left(v_{1 / 2}=49 \mathrm{~Hz}\right)$; IR (film) v: 1583 (s), 1453 (s), 1450 (s), 1316 (m), 1071 (m), 1032 (m), $863(\mathrm{~m}), 780(\mathrm{~s}), 766(\mathrm{~s}), 748(\mathrm{~m}) \mathrm{cm}^{-1}$. Magnetic susceptibility $\left(\mathrm{C}_{6} \mathrm{D}_{6}, 293 \mathrm{~K}\right): \mu_{\mathrm{eff}}=5.0(1) \mu_{\mathrm{B}}$. Anal. calcd for $\mathrm{C}_{32} \mathrm{H}_{33} \mathrm{FeN}_{2} \mathrm{OCl}_{4} \mathrm{P}$ : C 55.68, H 4.82, N 4.06; found C 55.57, $\mathrm{H} 4.80, \mathrm{~N} 4.10 .{ }^{57} \mathrm{Fe}$ Mössbauer spectrum (Zero-field, $80 \mathrm{~K}$ ) $\delta: 0.82 \mathrm{~mm} / \mathrm{s},\left|\Delta E_{\mathrm{Q}}\right|=2.40 \mathrm{~mm} / \mathrm{s}$.

\subsection{Preparation of $\left[\left(K^{3}-N, N, P_{-}{ }^{\mathrm{Mes}} \mathrm{N}_{2} \mathrm{P}^{\mathrm{Bu}-t}\right) \mathrm{Fe}\left(\eta^{2}-N, N-\right.\right.$ $\left.\left.(p \text {-tolyl })_{2} \mathrm{CN}_{2}\right)\right](3)$}

To a red solution of $\mathbf{1}(217 \mathrm{mg}, 0.34 \mathrm{mmol})$ in toluene (15 $\mathrm{mL})$ was added ( $p$-tolyl $)_{2} \mathrm{CN}_{2}(76 \mathrm{mg}, 0.34 \mathrm{mmol})$ at room temperature for $2 \mathrm{~h}$. The color of the solution changed from red to brown gradually. After removal of the solvent under vacuum, the brown residue was washed by $n$-pentane (10 $\mathrm{mL}$ ) to produce 3 as a brown solid (149 $\mathrm{mg}, 56 \%$ yield). Single-crystals of $\mathbf{3}$ suitable for X-ray diffraction study were obtained by standing its saturated $n$-pentane solution at room temperature via slow evaporation of $n$-pentane overnight. m.p. $>167{ }^{\circ} \mathrm{C}$ (dec.); ${ }^{1} \mathrm{H} \mathrm{NMR}\left(400 \mathrm{MHz}, \mathrm{C}_{6} \mathrm{D}_{6}\right.$, $293 \mathrm{~K}) \delta: 7.77(\mathrm{~d}, J=7.8 \mathrm{~Hz}, 2 \mathrm{H}), 7.31(\mathrm{t}, J=7.3 \mathrm{~Hz}, 2 \mathrm{H})$, $7.02(\mathrm{~d}, J=7.8 \mathrm{~Hz}, 2 \mathrm{H}), 6.94(\mathrm{t}, J=7.4 \mathrm{~Hz}, 2 \mathrm{H}), 6.61(\mathrm{t}$, $J=7.0 \mathrm{~Hz}, 4 \mathrm{H}), 6.43(\mathrm{~s}, 4 \mathrm{H}), 6.42 \sim 6.34(\mathrm{~m}, 2 \mathrm{H}), 5.80(\mathrm{~d}$, $J=7.9 \mathrm{~Hz}, 2 \mathrm{H}), 2.41(\mathrm{~s}, 6 \mathrm{H}), 2.07(\mathrm{~d}, J=20.5 \mathrm{~Hz}, 6 \mathrm{H}), 1.94$ (s, 6H), $1.62(\mathrm{~d}, J=15.4 \mathrm{~Hz}, 9 \mathrm{H}), 1.54(\mathrm{~s}, 6 \mathrm{H}) ;{ }^{13} \mathrm{C} \mathrm{NMR}$ $\left(101 \mathrm{MHz}, \mathrm{C}_{6} \mathrm{D}_{6}, 293 \mathrm{~K}\right) \delta: 170.99\left(\mathrm{~d}, J_{\mathrm{C}-\mathrm{P}}=24.5 \mathrm{~Hz}\right)$, $146.12,138.33,137.34,136.18,134.67,134.16,133.74$, $133.54,131.51,130.84,129.25,129.20,129.04,128.86$, $118.68,115.53,115.12,114.61,114.50,33.35\left(\mathrm{~d}, J_{\mathrm{C}-\mathrm{P}}=\right.$ $29.9 \mathrm{~Hz}), 27.80,21.34\left(\mathrm{~d}, J_{\mathrm{C}-\mathrm{P}}=7.2 \mathrm{~Hz}\right), 21.04,20.07$, $18.40 ;{ }^{31} \mathrm{P}$ NMR (162 MHz, $\left.\mathrm{C}_{6} \mathrm{D}_{6}, 293 \mathrm{~K}\right) \delta$ : 108.22; IR (film) v: 2967 (w), 2918 (m), 2867 (m), 2035 (s), 1593 (m), 1512 (s), 1451 (s), 1432 (s), 1316 (m), 1272 (m), 1064 (m), $1041(\mathrm{~m}), 858(\mathrm{w}), 813(\mathrm{~m}), 749(\mathrm{~m}), 623(\mathrm{w}), 566(\mathrm{w})$ $\mathrm{cm}^{-1}$. Anal. calcd for $\mathrm{C}_{49} \mathrm{H}_{53} \mathrm{FeN}_{4} \mathrm{P}: \mathrm{C} 74.99, \mathrm{H} 6.81, \mathrm{~N}$ 7.14; found C 75.20, H 6.75, N 7.40. ${ }^{57} \mathrm{Fe}$ Mössbauer spectrum (Zero-field, $80 \mathrm{~K}$ ) $\delta: 0.02 \mathrm{~mm} / \mathrm{s},\left|\Delta E_{\mathrm{Q}}\right|=2.98 \mathrm{~mm} / \mathrm{s}$. 
4.9 Preparation of $\left[\left(K^{3}-N, N, P-{ }^{\mathrm{Mes}} \mathrm{N}_{2} \mathrm{P}^{\mathrm{Bu}-t}\right) \mathrm{Fe}\left(\kappa^{2}-N, \mathrm{O}-\right.\right.$ $\left.\left.\mathrm{PhC}\left(\mathrm{N}_{2}\right) \mathrm{CO}_{2} \mathrm{Et}\right)\right](4)$

To a red solution of $\mathbf{1}(151 \mathrm{mg}, 0.24 \mathrm{mmol})$ in toluene (15 $\mathrm{mL}$ ) was added $\mathrm{PhC}\left(\mathrm{N}_{2}\right) \mathrm{CO}_{2} \mathrm{Et}(45 \mathrm{mg}, 0.24 \mathrm{mmol})$ at room temperature for $2 \mathrm{~h}$. The color of the solution changed from red to green gradually. After removal of the solvent under vacuum, the green residue was washed by $n$-pentane ( 10 $\mathrm{mL}$ ) to produce 4 as a green solid (108 $\mathrm{mg}, 60 \%$ yield). Single-crystals of $\mathbf{4}$ suitable for X-ray diffraction study were obtained by standing its saturated $n$-pentane solution at room temperature via slow evaporation of $n$-pentane overnight. m.p. $>160{ }^{\circ} \mathrm{C}$ (dec.); ${ }^{1} \mathrm{H}$ NMR $\left(400 \mathrm{MHz}, \mathrm{C}_{6} \mathrm{D}_{6}\right.$, $293 \mathrm{~K}) \delta: 34.16\left(v_{1 / 2}=41 \mathrm{~Hz}\right), 26.71\left(v_{1 / 2}=40 \mathrm{~Hz}\right), 24.59$ $\left(v_{1 / 2}=24 \mathrm{~Hz}\right), 22.33\left(v_{1 / 2}=20 \mathrm{~Hz}\right), 15.61\left(v_{1 / 2}=31 \mathrm{~Hz}\right)$, $-0.83\left(v_{1 / 2}=78 \mathrm{~Hz}\right),-31.30\left(v_{1 / 2}=45 \mathrm{~Hz}\right),-31.63\left(v_{1 / 2}\right.$ $=25 \mathrm{~Hz}),-52.10\left(v_{1 / 2}=47 \mathrm{~Hz}\right)$; IR (film) v: $2994(\mathrm{w})$, $2963(\mathrm{w}), 2920(\mathrm{w}), 2090(\mathrm{~m}), 1709(\mathrm{~m}), 1577(\mathrm{~s}), 1435(\mathrm{~s})$, $1371(\mathrm{~m}), 1288(\mathrm{~s}), 1276(\mathrm{~s}), 1255(\mathrm{~s}), 1195(\mathrm{~m}), 876(\mathrm{~m})$, $756(\mathrm{~m}), 741(\mathrm{w}) \mathrm{cm}^{-1}$. Magnetic susceptibility $\left(\mathrm{C}_{6} \mathrm{D}_{6}, 293\right.$ $\mathrm{K}): \mu_{\text {eff }}=3.2(1) \mu_{\mathrm{B}}$. Anal. calcd for $\mathrm{C}_{44} \mathrm{H}_{49} \mathrm{FeN}_{4} \mathrm{O}_{2} \mathrm{P}: \mathrm{C}$ $70.21, \mathrm{H} 6.56, \mathrm{~N} 7.44$; found C $69.49, \mathrm{H} 6.45, \mathrm{~N} 7.37 .{ }^{57} \mathrm{Fe}$ Mössbauer spectrum (Zero-field, $80 \mathrm{~K}) \delta: 0.25 \mathrm{~mm} / \mathrm{s},\left|\Delta E_{\mathrm{Q}}\right|$ $=2.55 \mathrm{~mm} / \mathrm{s}$.

\subsection{Catalytic conversion of ( $p$-tolyl $)_{2} \mathrm{CN}_{2}$ mediated by 2}

To a $\mathrm{C}_{6} \mathrm{D}_{6}$ solution $(0.2 \mathrm{~mL})$ of $2(5.1 \mathrm{mg}, 0.007 \mathrm{mmol})$ in a J-Young tube was added ( $p$-tolyl $)_{2} \mathrm{CN}_{2}(33 \mathrm{mg}, 0.148$ $\mathrm{mmol})$ and $\mathrm{C}_{6} \mathrm{D}_{6}(0.3 \mathrm{~mL})$ at room temperature. After $1 \mathrm{~h}$, an internal standard 1,3,5-trimethoxybenzene $(2.1 \mathrm{mg}$, $0.013 \mathrm{mmol}$ ) was then added. ${ }^{1} \mathrm{H}$ NMR analysis on the reaction mixture indicated the formation of the $(p \text {-tolyl })_{2}-$ $\mathrm{C}=\mathrm{NN}=\mathrm{C}(p \text {-tolyl })_{2}$ in $73 \%$ yield.

\subsection{Preparation of $\left[\left(\kappa^{3}-N, N, C-{ }^{\text {dcp }} N_{2} P^{\text {Bu-t }} C^{\mathrm{H}, \mathrm{Dmp}}\right) \mathrm{Fe}\right]$ (5)}

To an orange solution of $2(267 \mathrm{mg}, 0.47 \mathrm{mmol})$ in toluene $(15 \mathrm{~mL})$ was added $\operatorname{DmpC}\left(\mathrm{N}_{2}\right) \mathrm{H}(202 \mathrm{mg}, 0.57$ mmol). The mixture was then heated at $50{ }^{\circ} \mathrm{C}$ for $2 \mathrm{~h}$. The color of the solution changed from orange to yellow-green gradually. After removal of the solvent under vacuum, the yellow-green residue was washed by $n$-hexane $(10 \mathrm{~mL})$ and dried under vaccum, which leaved $\mathbf{5}$ as a yellow-green solid ( $270 \mathrm{mg}, 70 \%$ yield). Single-crystals of $\mathbf{5}$ suitable for X-ray diffraction study were obtained by standing its saturated $\mathrm{Et}_{2} \mathrm{O}$ solution at room temperature via slow evaporation of $\mathrm{Et}_{2} \mathrm{O}$ overnight. m.p. $>190{ }^{\circ} \mathrm{C}$ (dec.); ${ }^{1} \mathrm{H}$ NMR (400 MHz, $\left.\mathrm{C}_{6} \mathrm{D}_{6}, 293 \mathrm{~K}\right) \delta:{ }^{1} \mathrm{H}$ NMR (400 MHz, $\left.\mathrm{C}_{6} \mathrm{D}_{6}, 293 \mathrm{~K}\right) \delta: 61.44$ $\left(v_{1 / 2}=42 \mathrm{~Hz}\right), 44.44\left(v_{1 / 2}=31 \mathrm{~Hz}\right), 39.97\left(v_{1 / 2}=35 \mathrm{~Hz}\right)$, $36.05\left(v_{1 / 2}=32 \mathrm{~Hz}\right), 31.52\left(v_{1 / 2}=49 \mathrm{~Hz}\right), 30.36\left(v_{1 / 2}=55\right.$ $\mathrm{Hz}), 28.31\left(v_{1 / 2}=49 \mathrm{~Hz}\right), 23.74\left(v_{1 / 2}=29 \mathrm{~Hz}\right), 19.32\left(v_{1 / 2}=\right.$ $29 \mathrm{~Hz}), 17.62$ (very br), $16.82\left(v_{1 / 2}=36 \mathrm{~Hz}\right), 16.19\left(v_{1 / 2}=22\right.$ $\mathrm{Hz}), 15.45\left(v_{1 / 2}=54 \mathrm{~Hz}\right), 13.99\left(v_{1 / 2}=14 \mathrm{~Hz}\right), 12.73\left(v_{1 / 2}=\right.$ $21 \mathrm{~Hz}), 9.43\left(v_{1 / 2}=28 \mathrm{~Hz}\right),-7.61\left(v_{1 / 2}=203 \mathrm{~Hz}\right),-9.10$ (very br), $-15.32\left(v_{1 / 2}=28 \mathrm{~Hz}\right),-22.49 \quad\left(v_{1 / 2}=28 \mathrm{~Hz}\right)$, $-26.67\left(v_{1 / 2}=28 \mathrm{~Hz}\right),-36.60$ (very br), -36.68 (very br), $-37.36\left(v_{1 / 2}=32 \mathrm{~Hz}\right),-74.56$ (very br); IR (film) $v$ : $2963(\mathrm{~m}), 2916(\mathrm{~m}), 2864(\mathrm{~m}), 1587(\mathrm{~m}), 1553$ (w), 1468 (s), 1454 (w), 1443 (s), 1299 (m), 1293 (m), 1093 (w), 1067 (w), $867(\mathrm{w}), 847(\mathrm{~m}), 773(\mathrm{~m}), 743(\mathrm{~m}) \mathrm{cm}^{-1}$. Magnetic susceptibility $\left(\mathrm{C}_{6} \mathrm{D}_{6}, 293 \mathrm{~K}\right)$ : $\mu_{\mathrm{eff}}=4.9(1) \mu_{\mathrm{B}}$. Anal. calcd for $\mathrm{C}_{52} \mathrm{H}_{49} \mathrm{Cl}_{4} \mathrm{FeN}_{2} \mathrm{P}$ : C 67.53, H 5.24, N 2.97; found C 67.37, H $5.34, \mathrm{~N} 3.01 .{ }^{57} \mathrm{Fe}$ Mössbauer spectrum (Zero-field, $80 \mathrm{~K}$ ) $\delta$ : $0.70 \mathrm{~mm} / \mathrm{s},\left|\Delta E_{\mathrm{Q}}\right|=1.24 \mathrm{~mm} / \mathrm{s}$.

\subsection{Computational details}

To have a better understanding of the electronic structures of $\mathbf{3}$ and $\mathbf{4}$, density functional theory (DFT) ${ }^{[35-36]}$ study has been performed with the ORCA 4.1.0 program $^{[37]}$ using the B3LYP methods. ${ }^{[38-39]}$ The SVP ${ }^{[40-41]}$ basis set was used for the $\mathrm{C}, \mathrm{N}$, and $\mathrm{H}$ atoms, and the $\mathrm{TZVP}^{[42]}$ basis set was used for the other atoms. The RIJCOSX ${ }^{[43]}$ approximation with matching auxiliary basis sets ${ }^{[40-41]}$ was employed to accelerate the calculations. The calculation utilizes the atom-pairwise dispersion correction with the Becke-Johnson damping scheme (D3BJ). ${ }^{[44-45]}$ The atomic coordinates of $\mathbf{3}$ and $\mathbf{4}$ used for calculation were obtained from X-ray diffraction studies, and only the positions of hydrogen atoms were optimized. The selected localized orbitals for $\mathbf{3}$ are listed in Figures 3 and 4. The frontier molecular orbital diagram for $\mathbf{4}$ is listed in Figure 6.

Supporting Information NMR, IR, Mössbauer spectra for the new complexes, Table for crystal data (PDF). The Supporting Information is available free of charge via the Internet at http://sioc-journal.cn.

\section{References}

[1] Herrmann, W. A. Angew. Chem., Int. Ed. 1978, 17, 800.

[2] Sutton, D. Chem. Rev. 1993, 93, 995.

[3] Mizobe, Y.; Ishii, Y.; Hidai, M. Coord. Chem. Rev. 1995, 139, 281.

[4] Poverenov, E.; Leitus, G.; Shimon, L. J. W.; Milstein, D. Organometallics 2005, 24, 5937.

[5] Samant, R. G.; Graham, T. W.; Rowsell, B. D.; McDonald, R.; Cowie, M. Organometallics 2008, 27, 3070.

[6] Brookhart, M.; Studabaker, W. B. Chem. Rev. 1987, 87, 411.

[7] Chauvin, Y. Angew. Chem., Int. Ed. 2006, 45, 3740.

[8] Schrock, R. R. Angew. Chem., Int. Ed. 2006, 45, 3748.

[9] Grubbs, R. H. Angew. Chem., Int. Ed. 2006, 45, 3760.

[10] Zhu, S.-F.; Zhou, Q.-L. Natl. Sci. Rev. 2014, 1, 580.

[11] Albertin, G.; Antoniutti, S.; Forcolin, M.; Gasparato, D. Polyhedron 2016, 104, 46.

[12] Albertin, G.; Antoniutti, S.; Botter, A.; Castro, J. Inorg. Chem. 2015 $54,2091$.

[13] Albertin, G.; Antoniutti, S.; Castro, J.; Dottorello, G. Dalton Trans 2015, 44, 9289.

[14] Albertin, G.; Antoniutti, S.; Bortoluzzi, M.; Castro, J.; Marzaro, L. Dalton Trans 2015, 44, 15470.

[15] Werner, H.; Mahr, N.; Wolf, J.; Fries, A.; Laubender, M.; Bleuel, E.; Garde, R.; Lahuerta, P. Organometallics 2003, 22, 3566.

[16] Bonyhady, S. J.; Goldberg, J. M.; Wedgwood, N.; Dugan, T. R.; Eklund, A. G.; Brennessel, W. W.; Holland, P. L. Inorg. Chem. 2015, 54, 5148.

[17] Li, Y.; Huang, J.-S.; Zhou, Z.-Y.; Che, C.-M.; You, X.-Z. J. Am. Chem. Soc. 2002, 124, 13185.

[18] Bart, S. C.; Bowman, A. C.; Lobkovsky, E.; Chirik, P. J. J. Am. Chem. Soc. 2007, 129, 7212.

[19] Sazama, G. T.; Betley, T. A. Inorg. Chem. 2014, 53, 269.

[20] Bonyhady, S. J.; DeRosha, D. E.; Vela, J.; Vinyard, D. J.; Cowley, R. E.; Mercado, B. Q.; Brennessel, W. W.; Holland, P. L. Inorg. 
Chem. 2018, 57, 5959.

[21] Albertin, G.; Antoniutti, S.; Bortoluzzi, M.; Botter, A.; Castro, J.; Sibilla, F. RSC Adv. 2016, 6, 97650.

[22] Russell, S. K.; Hoyt, J. M.; Bart, S. C.; Milsmann, C.; Stieber, S. C. E.; Semproni, S. P.; DeBeer, S.; Chirik, P. J. Chem. Sci. 2014, 5, 1168 .

[23] Liu, J.; Hu, L.; Wang, L.; Chen, H.; Deng, L. J. Am. Chem. Soc. 2017, 139, 3876.

[24] Xiao, J.; Deng, L. Dalton Trans. 2013, 42, 5607.

[25] Smit, T. M.; Tomov, A. K.; Gibson, V. C.; White, A. J. P.; Williams, D. J. Inorg. Chem. 2004, 43, 6511.

[26] Cheng, J.; Liu, J.; Leng, X.; Lohmiller, T.; Schnegg, A.; Bill, E.; Ye, S.; Deng, L. Inorg. Chem. 2019, 58, 7634.

[27] Chisholm, M. H.; Folting, K.; Huffman, J. C.; Ratermann, A. L. Inorg. Chem. 1984, 23, 2303.

[28] Sydora, O. L.; Kuiper, D. S.; Wolczanski, P. T.; Lobkovsky, E. B.; Dinescu, A.; Cundari, T. R. Inorg. Chem. 2006, 45, 2008.

[29] Straub, B. F.; Rominger, F.; Hofmann, P. Organometallics 2000, 19, 4305.

[30] Olmstead, M. M.; Power, P. P.; Shoner, S. C. Inorg. Chem. 1991, $30,2547$.

[31] Javed, M. I.; Brewer, M. Org. Lett. 2007, 9, 1789.

[32] Iluc, V. M.; Laskowski, C. A.; Hillhouse, G. L. Organometallics
2009, 28, 6135.

[33] Evans, D. F. J. Chem. Soc. 1959, 2003.

[34] Sheldrick, G. M. SADABS: Program for Empirical Absorption Correction of Area Detector Data, University of Göttingen, Göttingen, Germany, 1996.

[35] Hohenberg, P.; Kohn, W. Phys. Rev. 1964, 136, B864.

[36] Kohn, W.; Sham, L. J. Phys. Rev. 1965, 140, A1133.

[37] Neese, F. ORCA-an ab initio, Density Functional and Semiempirical Program Package, Version 4.1.0, Max-Planck Institute for Bioinorganic Chemistry, Mulheim an der Ruhr, Germany, 2017.

[38] Becke, A. D. J. Chem. Phys. 1993, 98, 5648.

[39] Lee, C.; Yang, W.; Parr, R. G. Phys. Rev. B 1988, 37, 785.

[40] Schäfer, A.; Horn, H.; Ahlrichs, R. J. Chem. Phys. 1992, 97, 2571.

[41] Schäfer, A.; Huber, C.; Ahlrichs, R. J. Chem. Phys. 1994, 100, 5829.

[42] Pantazis, D. A.; Chen, X.-Y.; Landis, C. R.; Neese, F. J. Chem. Theory Comput. 2008, 4, 908.

[43] Neese, F.; Wennmohs, F.; Hansen, A.; Becker, U. Chem. Phys. 2009, 356, 98.

[44] Grimme, S.; Ehrlich, S.; Goerigk, L. J. Comput. Chem. 2011, 32, 1456.

[45] Grimme, S.; Antony, J.; Ehrlich, S.; Krieg, H. J. Chem. Phys. 2010, $132,154104$.

(Li, L.; Fan, Y.) 